Article

\title{
Analysis of Energy Consumption in Different European Cities: The Adaptive Comfort Control Implemented Model (ACCIM) Considering Representative Concentration Pathways (RCP) Scenarios
}

\author{
Daniel Sánchez-García ${ }^{1}\left(\mathbb{D}\right.$, David Bienvenido-Huertas ${ }^{1}{ }^{\mathbb{D}}$, Jesús A. Pulido-Arcas ${ }^{2}$ and \\ Carlos Rubio-Bellido ${ }^{1, *(1)}$ \\ 1 Department of Building Construction II, University of Seville, 41004 Seville, Spain; \\ sangardaniel@gmail.com (D.S.-G.); jbienvenido@us.es (D.B.-H.) \\ 2 Center for Global Communication Strategies, Graduate School of Arts and Sciences, The University of Tokyo, \\ Tokyo 113-8654, Japan; jpulido@aless.c.u-tokyo.ac.jp \\ * Correspondence: carlosrubio@us.es; Tel.: +34-686135595
}

Received: 23 January 2020; Accepted: 19 February 2020; Published: 23 February 2020

check for updates

\begin{abstract}
Reports of Intergovernmental Panel on Climate Change have set various greenhouse gas emissions scenarios, through which the evolution of the temperature of the planet can be estimated throughout the 21st century. The reduction of the emissions from the different activities carried out by mankind is crucial to mitigate greenhouse gas emissions. One of the most significant activities is users' behaviour within buildings, particularly the use of Heating, Ventilation and Air-Conditioning systems. Modifying users' behaviour patterns to guarantee acceptable thermal conditions inside buildings could lead to considerable energy saving percentages, and adaptive thermal comfort models could be an opportunity to achieve important savings. For this reason, this study analyzes the potential to apply adaptive thermal comfort models to use artificial air-conditioning systems by modifying setpoint temperatures. The analysis was conducted in five major European cities (Barcelona, Berlin, Bern, Rome, and Vienna) and in five climate change scenarios in the year 2050. The results showed that, in general, the energy saving achieved by adaptive strategies was larger in the cities with a greater cooling demand. Also, in both Representative Concentration Pathways (RCP) of the Fifth Assessment Report (AR5) considered, the energy saving were decreased in the cities of Barcelona and Rome, with values lower than those of the Fourth Assessment Report (AR4) scenarios considered, whereas in the cities of Berlin, Bern, and Vienna, the saving in the RCP scenarios is greater than those in the other scenarios.
\end{abstract}

Keywords: climate change; RCP scenarios; SRES scenarios; building; energy consumption; HVAC system; setpoint temperature; adaptive thermal comfort

\section{Introduction}

One of the goals of buildings is serving as a refuge for people from external climate conditions by using Heating, Ventilation and Air-Conditioning (HVAC) systems. However, using them excessively could decrease the capacity of people to adapt to the variations of the ambient temperature in a physiological and psychological way [1].

On the other hand, the effects from climate change are becoming more and more significant each year. Climate change originated by the decisions taken by human beings without considering their environmental impact [2]. Taking as a reference the surface temperature from the pre-industrial 
period, the temperature could increase between values close to $2.5^{\circ} \mathrm{C}$ in $2050,4.5^{\circ} \mathrm{C}$ in $2100,7.5^{\circ} \mathrm{C}$ in 2200 , and $8^{\circ} \mathrm{C}$ in 2300 [3]. With the need to regulate the emission of pollutant gases and the resource depletion, it is established that the building sector reduces the greenhouse gas emissions by $90 \%$ by 2050 [4]. Based on the poor energy performance of buildings [5] and users' behaviour [6], data show that the total energy consumption between $30 \%$ and $40 \%$ [7], and the $40 \%$ of greenhouse gas emissions correspond to the building sector $[8,9]$.

Currently, the European standard EN 19798-1:2019 is the basic legal framework that regulates the indoor environmental parameters for thermal environment, indoor air quality, lighting and acoustics in buildings; as for the first topic, the standard recommends lower and upper set-point temperatures for both heating and cooling, depending on three categories of buildings. Heating setpoints range from 16 to 21 degrees for heating and from 25.5 to 28 degrees for cooling in the main residential and living spaces; an additional fourth category may exceptionally find application in spaces that do not meet the former criteria.

The main energy conservation measures are usually the improvement of envelopes and the improvement of HVAC systems. Nevertheless, to avoid significant economic investments, as occurs with these energy conservation measures, the rational and appropriate use of HVAC systems has been extensively studied by varying setpoint temperatures: (i) Hoyt et al. [10] used cooling and heating setpoint temperatures of $27.87^{\circ} \mathrm{C}$ and $18.3^{\circ} \mathrm{C}$, respectively, in an office building located in different cities of United States, obtaining an energy saving between 32 and 73\%; (ii) Parry et al. [11] analyzed that an increase of the cooling setpoint temperature between 2 and $4{ }^{\circ} \mathrm{C}$ in an office building in Zurich would generate an annual energy saving of $66 \%$; (iii) Wan et al. [12] observed that cooling setpoint temperatures greater than $25.5^{\circ} \mathrm{C}$ obtained savings in the cooling demand, both in current and future scenarios; (iv) Lakeridou et al. [13] observed that increasing the cooling setpoint temperature by 2 ${ }^{\circ} \mathrm{C}$ in a field study carried out in an administrative building did not affect the thermal comfort; (v) Spyropoulos and Balaras [14] used setpoint temperatures of $20^{\circ} \mathrm{C}$ for heating and $26^{\circ} \mathrm{C}$ for cooling, thus generating energy savings of up to $45 \%$; (vi) Fernandez et al. [15] observed that by applying a series of energy conservation measures, including the decrease of heating and the increase of cooling setpoint temperatures by $1.1^{\circ} \mathrm{C}$, the energy savings obtained ranged between 12 and $20 \%$.

As previously mentioned, these research studies allowed the energy consumption to be reduced by varying the setpoint temperatures, although such setpoints were static (i.e., Predicted Mean Vote Index (PMV)-based). On the other hand, there is an increasing tendency in the number of studies which apply adaptive setpoint temperatures by assigning the value of lower and upper adaptive comfort limits to heating and cooling setpoint temperatures, respectively. This technique is widely used as most of the climate of the planet have possibilities of application in more than $50 \%$ of the days of the year [16]. The most important research studies are as follows: (i) Sánchez-Guevara Sánchez et al. [17] applied setpoint temperatures based on the comfort limits of the simplified model from ASHRAE 55-2013 [18], varying monthly, in three residential buildings located in various cities of Spain. Energy consumption was reduced by $20 \%$ and $80 \%$ in heating and cooling, respectively; (ii) Van der Linden et al. [19] analyzed the energy saving achieved by the thermal comfort model from ISSO74 [20]. The use of the lower limit of such standard as the heating setpoint temperature achieved an energy saving of 74\%; (iii) Sánchez-García et al. [21] developed the Adaptive Comfort Control Implemented Model (ACCIM), which consists of a Building Energy Model (BEM) to which these adaptive setpoint temperatures are applied. Daily adaptive setpoint temperatures were used in a residential building located in the same cities on which the study by Sánchez-Guevara Sánchez et al. was based [17], and energy savings between 10 and $46 \%$ were achieved according to the type of climate; (iv) Sánchez-García et al. [22] observed that the application of the ACCIM, together with the use of the mixed-mode in an administrative building located in the south of Spain, achieved savings between 36.7 and 59.5\% in the building energy consumption; (v) Sánchez-García et al. [23] analyzed the energy savings achieved according to the three categories from the EN 15251:2007 standard [24]. The results showed that the energy saving was $31.34 \%$ and $69.91 \%$ for the categories I 
and III, respectively; (vi) Bienvenido-Huertas et al. [25] applied adaptive setpoint temperatures based on EN 15251:2007, EN 16798-1:2019, and ASHRAE 55-2017 standards in an office building located in 65 cities; (vii) Bienvenido-Huertas et al. [26] studied the energy and economic feasibility of carrying out different energy conservation measures of façades by applying adaptive setpoint temperatures.

It is necessary to consider that these research studies where carried out in mild and cold climates, in which the climates of the cities of Barcelona, Rome, Berlin, Bern, and Vienna are included. The choice of the cities could be therefore justified, considering that these climates include the zones with the greatest population of Europe.

This research aims to analyze the energy consumption resulting from applying the ACCIM in the current scenario, as well as in future scenarios influenced by climate change, considering not just the scenarios included in the Special Report on Emissions Scenarios (SRES), but also the Representative Concentration Pathway (RCP) scenarios, all in the year 2050. So, the saving from applying the ACCIM based on the EN16798 standard instead of the static comfort model could be assessed, as well as the variations in the consumption from the evolution of the various future climate scenarios with respect to current scenario.

\section{Methodology}

\subsection{Thermal Comfort Models: Adaptive and Static}

Static comfort models (i.e., PMV-based) were originally based on the theory of thermal comfort developed by Fanger [27], and later on, standards were developed through extensive fieldwork conducted in air-conditioned office buildings with some limitations; occupants were considered to be engaged in sedentary activities, and their level of clothing was between 0.5 CLO during summer and 2 CLO during winter; therefore, the mechanisms of thermal adaptation were scarce, especially regarding the operation of the building and the interaction with the external climate [28].

This model and the subsequent standards have been considered a keystone for assessing thermal comfort over the last 40 years, although their applicability has been being reconsidered in recent times. As an example, previous research has highlighted that caution should be exercised when using those standards in the design of air-conditioned buildings because, indeed, those were intended to be applied under very specific conditions [29]. Furthermore, uncertainty in measurements must be also considered as well as in surveys of subjective occupant's evaluation [30]. On top of that, the recent advance in computational capacity has brought a catalogue of calculation tools for the PMV not only for personal computers, but also for smartphones, whose oversimplification in both the input data and the calculation procedure might lead to wrong results [31].

In contrast, adaptive comfort models have been developed in offices without HVAC systems (i.e., free-running offices), where occupants can freely interact with the building to achieve thermal comfort, either by opening or closing windows, changing their clothes or having cold drinks; in short, occupants are able to adapt, to a certain extent, to the internal ambient temperature [31,32].

At the present time, the adaptive thermal comfort model in Europe, which is also used in this research, is that from the EN 16798-1:2019 standard [33], which supersedes its predecessor EN 15251:2007 [24]. This standard defines three different categories according to occupants' expectations and the type of building (e.g., category I should be used in spaces for people with special requirements, such as old people or ills; category II should be used in new buildings; and category III should be used in existing buildings). These three categories also differ in the amplitude of the comfort zone: category I has an amplitude of $5{ }^{\circ} \mathrm{C}$; category II has an amplitude of $7{ }^{\circ} \mathrm{C}$; and category III has an amplitude of 9 ${ }^{\circ} \mathrm{C}$. This study deals with an existing building, so category III is adopted.

Adaptive comfort limits are established by linear correlations (Equations (1) and (2)). The independent variable is the running mean outdoor temperature (RMOT), which is obtained by the weighted average of the daily external average temperatures of the previous days (Equation (3)). Therefore, if the RMOT is between the upper applicability limit $\left(30^{\circ} \mathrm{C}\right)$ and the lower applicability 
limit $\left(10^{\circ} \mathrm{C}\right)$, the adaptive thermal comfort model is applicable and the adaptive comfort limits can therefore be established. The operative internal temperature should be within these limits to achieve thermal comfort.

$$
\begin{gathered}
\text { Upper limit }(\text { Category III })=0.33 \cdot T_{r m}+18.8+4 \quad\left[{ }^{\circ} \mathrm{C}\right] \quad\left(10 \leq T_{r m} \leq 30\right) \\
\text { Lower limit }(\text { Category III })=0.33 \cdot T_{r m}+18.8-5 \quad\left[{ }^{\circ} \mathrm{C}\right] \quad\left(10 \leq T_{r m} \leq 30\right) \\
\text { RMOT }=\left(T_{\text {ext,d-1 }}+0.8 T_{\text {ext }, d-2}+0.6 T_{\text {ext }, d-3}+0.5 T_{\text {ext }, d-4}+0.4 T_{\text {ext }, d-5}+0.3 T_{\text {ext }, d-6}+0.2 T_{\text {ext }, d-7}\right) / 3.8
\end{gathered}
$$

In the adaptive model, setpoint temperatures vary according to the RMOT: (i) If the RMOT is lower than $10^{\circ} \mathrm{C}$, setpoint temperatures are calculated by using the minimum applicable RMOT (i.e., Heating Setpoint Temperature $($ HST $)=0.33 \cdot 10+13.8=17.1$; Cooling Setpoint Temperature $($ CST $)=$ $0.33 \cdot 10+22.8=26.1$ ); (ii) if the RMOT is between 10 and $30^{\circ} \mathrm{C}$, setpoint temperatures are calculated by using the RMOT in question; and (iii) if the RMOT is greater than $30^{\circ} \mathrm{C}$, setpoint temperatures are calculated by using the maximum applicable RMOT (i.e., $H S T=0.33 \cdot 30+13.8=23.7$; $C S T=$ $0.33 \cdot 30+22.8=32.7)$. On the other hand, in the static model, setpoint temperatures vary on the basis of the category of the building and the period of the year: In this case, buildings are considered to fall under category II, which means that during the cooling period, from 1 May to 30 September, the HST and CST are 23 and $26^{\circ} \mathrm{C}$, respectively; the rest of the year is considered a heating period, when the HST and CST are $20^{\circ} \mathrm{C}$ and $25^{\circ} \mathrm{C}$, respectively. Table 1 summarizes the setpoint temperatures for each model.

Table 1. Heating (HST) and cooling (CST) setpoint temperatures for each model.

\begin{tabular}{ccccccc}
\hline \multirow{2}{*}{ Model } & \multicolumn{7}{c}{ Setpoint Temperature [ $\left.{ }^{\circ} \mathrm{C}\right]$} \\
\cline { 2 - 7 } & \multicolumn{2}{c}{$T_{r m}<10$} & \multicolumn{2}{c}{$10 \leq T_{r m} \leq 30$} & $T_{r m}>30$ \\
\cline { 2 - 8 } & HST & CST & HST & CST & HST & CST \\
\hline Adaptive & 17.1 & 26.1 & $0.33 \cdot T_{r m}+18.8-5$ & $0.33 \cdot T_{r m}+18.8+4$ & 23.7 & 32.7 \\
Static & $20^{\mathrm{a}} 23^{\mathrm{b}}$ & $25^{\mathrm{a}} 26^{\mathrm{b}}$ & $20^{\mathrm{a}} 23^{\mathrm{b}}$ & $25^{\mathrm{a}} 26^{\mathrm{b}}$ & $20^{\mathrm{a}} 23^{\mathrm{b}}$ & $25^{\mathrm{a}} 26^{\mathrm{b}}$ \\
\hline
\end{tabular}

${ }^{\mathrm{a}}$ Heating setpoint ${ }^{\mathrm{b}}$ Cooling setpoint.

\subsection{Case Study and Simulation}

This case study corresponds to an experimental prototype reproducing usual parameters in residential buildings (Figure 1) and based on other existing research studies on the subject [34,35]. The prototype is an intermediate floor so slabs and ceilings can be considered adiabatic and heat transfers between the interior and the exterior occur only through the external walls. Likewise, all rooms except for the stairwell were considered as air-conditioned zones, and the same setpoint temperatures were used in all of them. The thermal properties of the opaque elements are specified in Table 2. As for windows, a design with a thermal transmittance of $4.2 \mathrm{~W} /\left(\mathrm{m}^{2} \mathrm{~K}\right)$ and a constant solar heat gain coefficient of 0.6 was considered.

Table 2. Thermal properties of the vertical elements.

\begin{tabular}{cccccc}
\hline \multirow{2}{*}{ Element } & Layer & Thickness $[\mathbf{m}]$ & $\begin{array}{c}\text { Thermal } \\
\text { Capacity } \\
{[\mathbf{J} / \mathbf{( k g K )}]}\end{array}$ & $\begin{array}{c}\text { Density } \\
{\left[\mathbf{k g} / \mathbf{m}^{3}\right]}\end{array}$ & $\begin{array}{c}\text { Thermal } \\
\text { Conductivity } \\
{[\mathbf{W} /(\mathbf{m K})]}\end{array}$ \\
\hline \multirow{3}{*}{ External wall } & 1.Perforated brick & 0.115 & 1000 & 780 & 0.350 \\
\cline { 2 - 6 } & 2.Cement mortar & 0.015 & 1000 & 1700 & 1.000 \\
\cline { 2 - 6 } & 3.EPS insulation & 0.020 & 1450 & 50 & 0.032 \\
\cline { 2 - 6 } & 4.Hollow brick & 0.070 & 1000 & 770 & 0.320 \\
\hline \multirow{2}{*}{ 5.Gypsum plaster } & 0.015 & 1000 & 1000 & 0.570 \\
\cline { 2 - 6 } & 1. Plasterboard & 0.025 & 1000 & 900 & - \\
\cline { 2 - 6 } & 2. Air gap & 0.100 & - & 900 & 0.250 \\
\hline
\end{tabular}




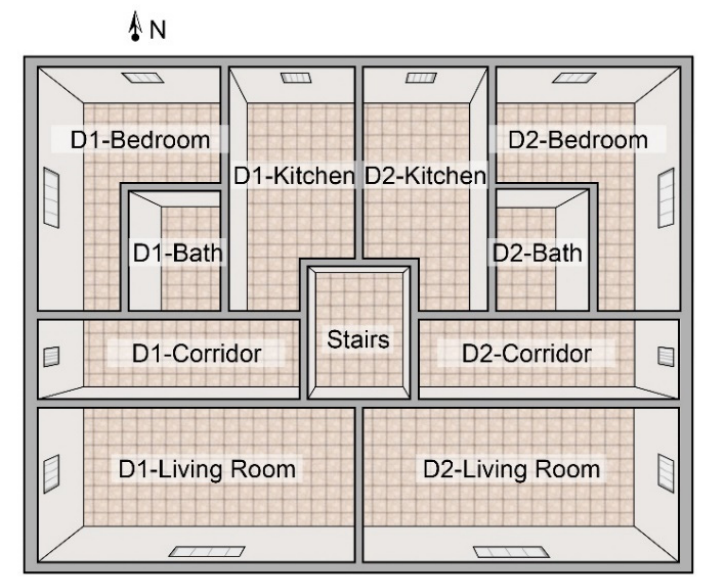

(a)

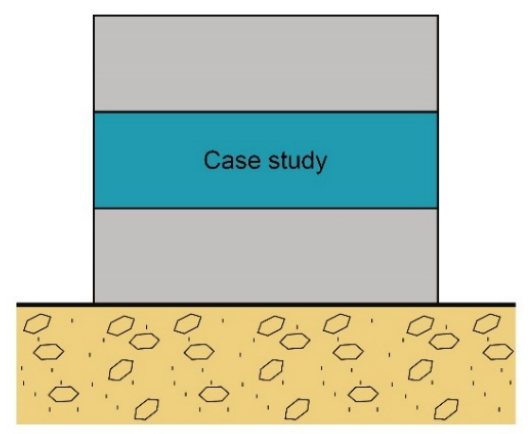

(b)

Figure 1. Dwelling prototype. 3D plan (a) and schematic section (b).

With respect to the loads schedule, data similar to previous research studies was used [21,23,35] (Table 3). All internal loads vary depending on the day of the week (weekdays and weekends). Regarding HVAC equipment, a Variable Refrigerant Flow (VRF) system is used for both heating and cooling, with a Coefficient of Performance (COP) of 3.10 and an Energy Efficiency Ratio (EER) of 3.00. The HVAC system did not include mechanical ventilation, and the airflow was set at a constant rate of $0.5 \mathrm{ac} / \mathrm{h}$ due to the infiltration of windows.

Table 3. Loads schedule in the case study.

\begin{tabular}{|c|c|c|c|c|c|c|c|c|}
\hline \multicolumn{9}{|c|}{ Loads Schedule } \\
\hline \multirow{2}{*}{\multicolumn{2}{|c|}{ Loads }} & \multicolumn{7}{|c|}{ Time Period } \\
\hline & & $1: 00-7: 00$ & $8: 00$ & 09:00-15:00 & $16: 00-18: 00$ & 19:00 & 20:00-23:00 & 00:00 \\
\hline \multirow{2}{*}{$\begin{array}{l}\text { Sensible load } \\
\qquad\left(\mathrm{W} / \mathrm{m}^{2}\right)\end{array}$} & Weekdays & 2.15 & 0.54 & 0.54 & 1.08 & 1.08 & 1.08 & 2.15 \\
\hline & Weekend & 2.15 & 2.15 & 2.15 & 2.15 & 2.15 & 2.15 & 2.15 \\
\hline \multirow{2}{*}{$\begin{array}{l}\text { Latent load } \\
\qquad\left(\mathrm{W} / \mathrm{m}^{2}\right)\end{array}$} & Weekdays & 1.36 & 0.34 & 0.34 & 0.68 & 0.68 & 0.68 & 1.36 \\
\hline & Weekend & 1.36 & 1.36 & 1.36 & 1.36 & 1.36 & 1.36 & 1.36 \\
\hline $\begin{array}{l}\text { Lighting } \\
\left(\mathrm{W} / \mathrm{m}^{2}\right)\end{array}$ & $\begin{array}{l}\text { Weekdays } \\
\text { andweekend }\end{array}$ & 0.44 & 1.32 & 1.32 & 1.32 & 2.20 & 4.40 & 2.20 \\
\hline $\begin{array}{l}\text { Equipment } \\
\left(\mathrm{W} / \mathrm{m}^{2}\right)\end{array}$ & $\begin{array}{l}\text { Weekdays } \\
\text { andweekend }\end{array}$ & 0.44 & 1.32 & 1.32 & 1.32 & 2.20 & 4.40 & 2.20 \\
\hline
\end{tabular}

The prototype was modelled using the software package EnergyPlus ${ }^{\circledR}$. All data regarding geometry, thermal properties and internal loads were input as specified in this section and were left unchanged, thus being considered control variables. The independent variables were the external temperature and relative humidity for each of the considered cities, as specified in the following sections; amongst the output variables that the software delivers, two of them were selected as dependent variables for this study: Energy consumption and thermal comfort levels, which are defined as follows.

Energy consumption is the total energy consumption of the HVAC system over the period of 1 year to keep the operative temperature of a single apartment unit within the limits as per the static or the adaptive model (Table 1). Thermal comfort levels are assessed using the following categories: (i) Comfortable Hours, when the RMOT falls within the applicability limits of the adaptive comfort model and the operative temperature is also within the setpoint temperatures; (ii) Discomfortable Applicable Hot Hours, which are the hours in which the RMOT is within the applicability limits, but the operative temperature overcomes the CST; (iii) Discomfortable Applicable Cold Hours, which are the hours in which the RMOT is within the applicability limits, but the operative temperature is lower than the HST; (iv) Discomfortable Non-Applicable Hot Hours, which are the hours in which the RMOT overcomes the upper applicability limit; (v) Discomfortable Non-Applicable Cold Hours, 
which are the hours in which the RMOT is lower than the lower applicability limit; and Hours within setpoint temperatures, which are the hours in which the operative temperature is within the setpoint temperatures, regardless of whether the adaptive model is applicable or not. When the operative temperature falls under categories (iv) or (v), HVAC systems come into play to keep internal conditions acceptable for buildings under category III as per ISO 16798: The PPD must be under $15 \%$ and the PMV must be between \pm 0.7 . Occupants are considered to wear 1 CLO during winter and 0.5 CLO during summer and be engaged in sedentary activities (1.2 MET).

Other conditions, such as local thermal discomfort, air quality, noise levels, and lighting have not been considered in the simulations; besides, no solar obstacles are included in the model, thus the building is isolated.

\subsection{Locations}

The locations for this study were chosen with regard to the fact that RCP scenarios foresee a considerable increase of radiative forcing (RF) in highly populated and developed areas. For this reason, Barcelona, Berlin, Bern, Rome, and Vienna were included as they are heavily populated and have different climates.

According to the Köppen-Geiger classification, the climate of Barcelona and Rome is Csa, which is characterized by dry and hot summers and mild winters. On the other hand, the climate of Berlin, Bern, and Vienna is $\mathrm{Cfb}$, which is an oceanic climate with no severe winters. Figure 2 shows the daily mean maximum and minimum outdoor temperatures and relative humidity: The daily mean maximum outdoor temperatures in July are $29.3^{\circ} \mathrm{C}$ and $31.1^{\circ} \mathrm{C}$ in Barcelona and Rome, respectively, and $23.1^{\circ} \mathrm{C}, 23.5^{\circ} \mathrm{C}$, and $24.7^{\circ} \mathrm{C}$ in Berlin, Bern, and Vienna, respectively, whereas the daily mean minimum outdoor temperatures in January are $7.8^{\circ} \mathrm{C}$ and $6.2^{\circ} \mathrm{C}$ in Barcelona and Rome, respectively, and $1.1^{\circ} \mathrm{C},-0.2{ }^{\circ} \mathrm{C}$, and 0.2 in Berlin, Bern, and Vienna, respectively.
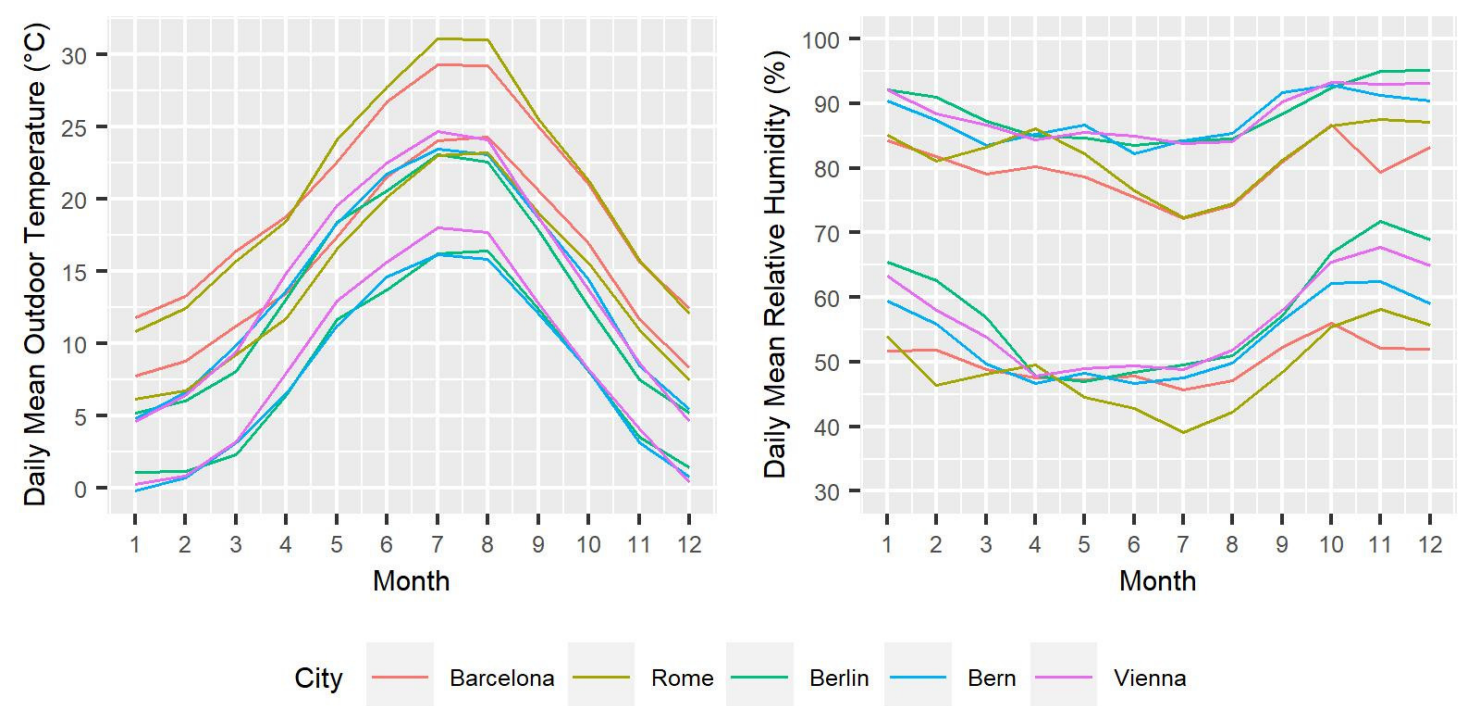

Figure 2. Daily mean maximum and minimum outdoor temperatures in each city (left) and relative humidity (right).

\subsection{Climate Change Scenarios}

The Fourth Assessment Report (AR4) [36] was released by the Intergovernmental Panel on Climate Change (IPCC) in 2007, which used 23 models based on the third phase of the Coupled Model Intercomparison Project (CMIP3). Seven years later, the IPCC released the Fifth Assessment Report (AR5), but used more than 50 models to report climate projections [37], whose information was provided by the fifth phase of the Coupled Model Intercomparison Project (CMIP5) [38]. 
The SRES scenarios are 40 in total, each scenario based on various hypotheses related to the future pollution of greenhouse gas emissions, land-uses and other driving forces. In such way, hypotheses are considered in the future technological development and the future economic development for each scenario. Scenarios are classified into families, whose scenarios have some similar aspects. The families of the scenarios used in the Third and Fourth Assessment Reports are A1FI, A1B, A1T, A2, B1, and B2. The combination of a series of hypotheses therefore results in the variation of the climate conditions of the future scenario.

Also, a series of new scenarios called RCP was developed. These scenarios are called pathways to stress that they are not definitive scenarios, but internally consistent sets of time-dependent forcing projections. They are identified by the approximate value of the $\mathrm{RF}\left(\mathrm{in} \mathrm{W} / \mathrm{m}^{2}\right.$ ) at 2100 or at stabilisation after 2100 in their extensions, relative to pre-industrial values. There are four RCP scenarios: RCP2.6 (the lowest of the four, also referred to as RCP3-PD) peaks at $3.0 \mathrm{~W} / \mathrm{m}^{2}$ and then declines to $2.6 \mathrm{~W} / \mathrm{m}^{2}$ in 2100, RCP4.5 (medium-low) and RCP6.0 (medium-high) stabilize after 2100 at 4.2 and $6.0 \mathrm{~W} / \mathrm{m}^{2}$ respectively, while RCP8.5 (the highest) reaches $8.3 \mathrm{~W} / \mathrm{m}^{2}$ in 2100 on a rising trajectory [39].

This research has considered these five scenarios: SRES A1B, A2, B1, RCP4.5, and RCP 8.5. As the first step of the study, the daily mean outdoor temperature and the average relative humidity for each location and each scenario were generated, taking as a base the available meteorological files of each city, which compile data from the period 2000-2009. As a result, new meteorological files were generated and subsequently input to EnergyPlus to calculate the energy consumption and the thermal comfort levels under each scenario (Figure 3).

Daily mean maximum and minimum outdoor temperatures significantly increase in the RCP4.5 and RCP8.5 scenarios, as well as the daily mean maximum and minimum relative humidity decrease (Figure 3). Table 4 shows that daily mean outdoor temperatures highly increases in the RCP4.5 and RCP8.5 scenarios, with an average among all cities of $2.10^{\circ} \mathrm{C}$ and $2.97^{\circ} \mathrm{C}$ in the maximum, and $1.72{ }^{\circ} \mathrm{C}$ and $2.45^{\circ} \mathrm{C}$ in the minimum, respectively, whereas A1B and A2 scenarios have an increase of $0.81^{\circ} \mathrm{C}$ and $0.74{ }^{\circ} \mathrm{C}$, and $0.81{ }^{\circ} \mathrm{C}$ and $0.65{ }^{\circ} \mathrm{C}$, respectively. As for the $\mathrm{B} 1$ scenario, the average is the lowest, with $0.38^{\circ} \mathrm{C}$ in the maximum and $0.31^{\circ} \mathrm{C}$ in the minimum. It must be understood that the temperatures mentioned in this section and shown in Figure 3 and Table 4 represent a likely approximation of those from the years 2050, and therefore, according to the Hadley Centre Technical Note 44 [42], an uncertainty limit of $\pm 5 \%$ must be assumed.

Table 4. Increase of average daily maximum and minimum outdoor temperatures in the different future scenarios with respect to the current scenario, with an uncertainty limit of $\pm 5 \%$.

\begin{tabular}{|c|c|c|c|c|c|c|}
\hline \multirow{2}{*}{ Temperature } & \multirow{2}{*}{ City } & \multicolumn{5}{|c|}{ Scenario } \\
\hline & & A1B & A2 & B1 & RCP4.5 & RCP8.5 \\
\hline \multirow{6}{*}{$\begin{array}{l}\text { Avg Daily Max } \\
\left(\Delta^{\circ} \mathrm{C}\right)\end{array}$} & Barcelona & 1.11 & 1.04 & 0.56 & 1.95 & 3.03 \\
\hline & Rome & 0.66 & 0.58 & 0.21 & 2.60 & 3.12 \\
\hline & Berlin & 0.94 & 0.85 & 0.54 & 1.89 & 2.40 \\
\hline & Bern & 0.72 & 0.56 & 0.22 & 1.86 & 3.06 \\
\hline & Vienna & 0.64 & 0.65 & 0.36 & 2.18 & 3.23 \\
\hline & Mean & 0.81 & 0.74 & 0.38 & 2.10 & 2.97 \\
\hline \multirow{6}{*}{$\begin{array}{c}\text { Avg Daily Min } \\
\left(\Delta^{\circ} \mathrm{C}\right)\end{array}$} & Barcelona & 1.12 & 1.04 & 0.47 & 1.86 & 2.81 \\
\hline & Rome & 0.62 & 0.47 & 0.13 & 2.51 & 2.92 \\
\hline & Berlin & 0.95 & 0.77 & 0.60 & 1.29 & 1.80 \\
\hline & Bern & 0.64 & 0.53 & 0.13 & 1.12 & 2.38 \\
\hline & Vienna & 0.72 & 0.45 & 0.22 & 1.84 & 2.35 \\
\hline & Mean & 0.81 & 0.65 & 0.31 & 1.72 & 2.45 \\
\hline
\end{tabular}



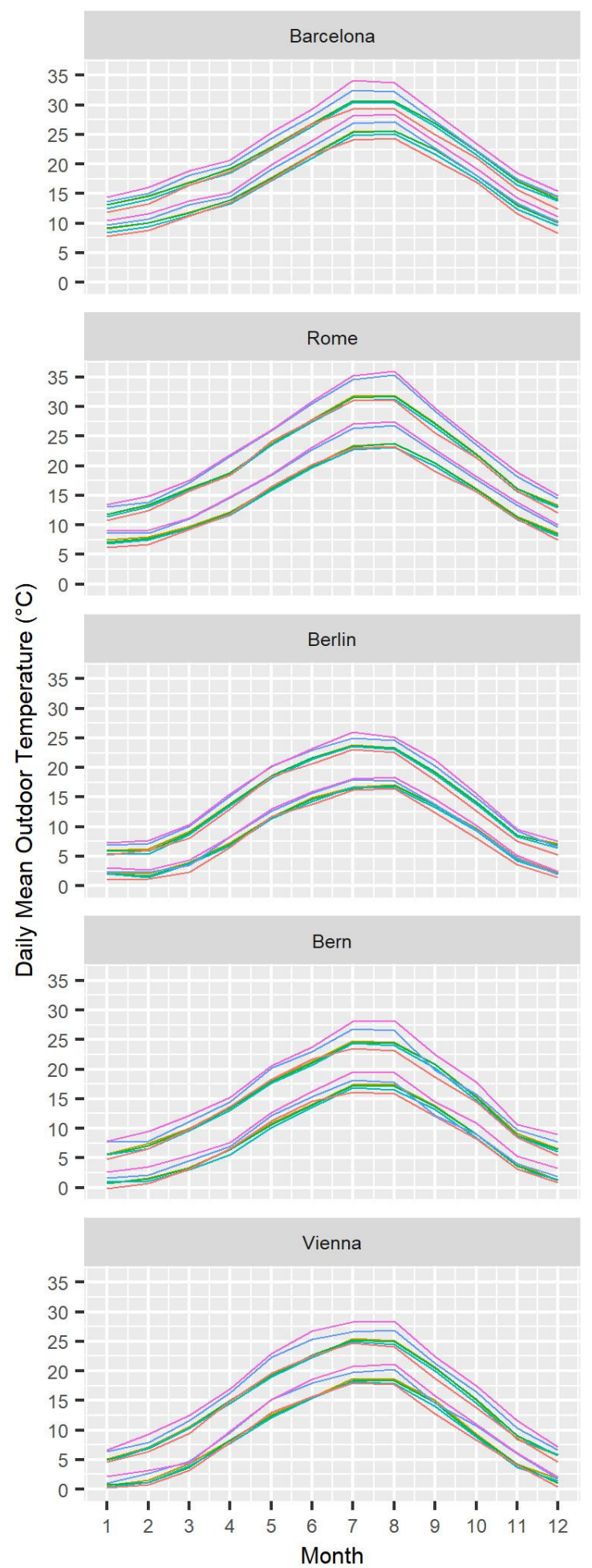
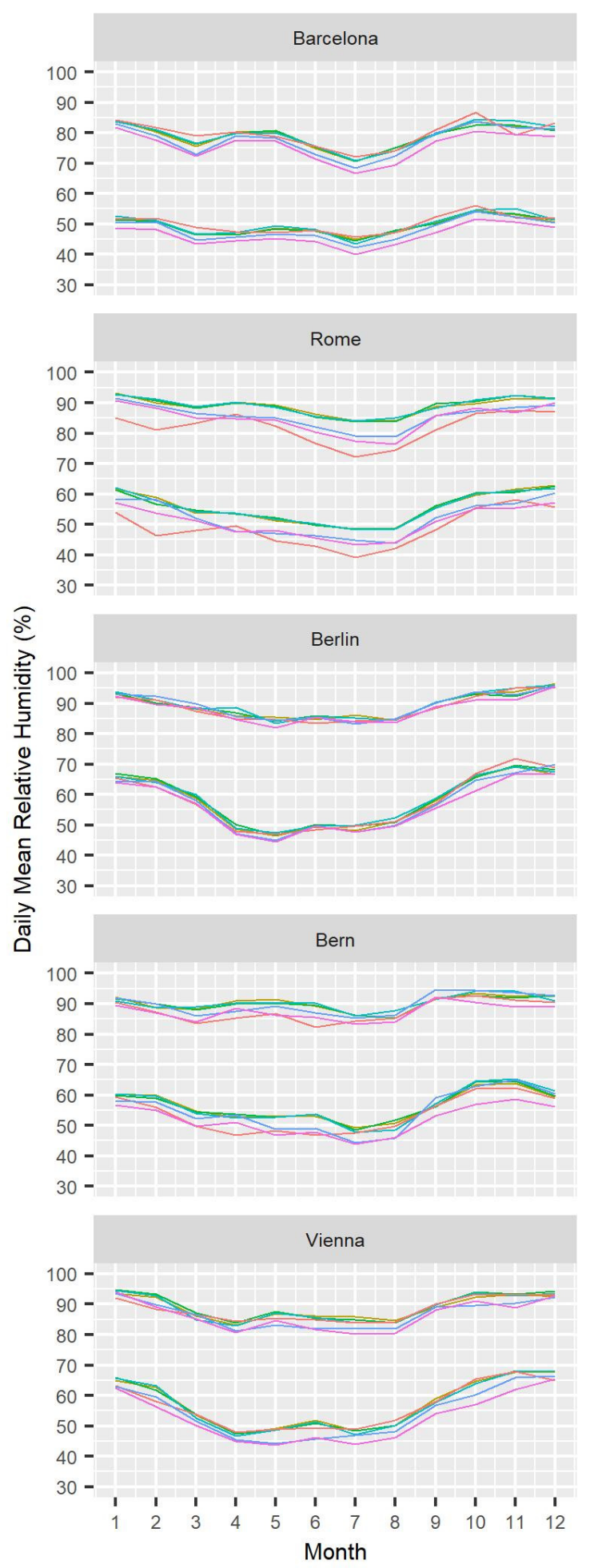

$$
\begin{aligned}
\text { Scenario }- \text { Current }-\mathrm{A} 2-\mathrm{RCP} 4.5 \\
-\mathrm{A} 1 \mathrm{~B}-\mathrm{B} 1-\mathrm{RCP} 8.5
\end{aligned}
$$

Figure 3. Increase of the daily mean outdoor temperature and relative humidity for each climate scenario.

\section{Results and Discussion}

For each city, 12 simulations were run: One corresponding for the current scenario and five for each future scenario (2050 A1B, 2050 A2, 2050 B1, 2050 RCP4.5, and 2050 RCP8.5); as both the static and the adaptive comfort models were considered (EN 16798-1 Static and EN 16798-1 Adaptive), two 
runs were necessary for each one of these six simulations, accounting for a total of 12 . Therefore, 60 simulations were done for the five cities.

Section 3.1 analyzes the potential of reduction of energy consumption when the static and the adaptive model are considered; Section 3.2 comments on the variation of the energy consumption as a function of the future climate scenarios; Section 3.3 includes information about the thermal comfort levels.

\subsection{Comparison of Energy Consumption Based on the Comfort Model, Cities, and Scenarios}

The results of consumption in Figure 4 show significant differences in the energy consumption between the cities of Barcelona and Rome, varying between 883.07 and $1857.25 \mathrm{kWh} /$ year according to the scenario and city, and in the cities of Berlin, Bern, and Vienna, between 2474.58 and 3705.98 $\mathrm{kWh} /$ year. The main reason is that Barcelona and Rome are located in warmer climates (Csa, according to Köppen-Geiger) than Berlin, Bern, and Vienna ( $\mathrm{Cfb}$, according to Köppen-Geiger). Focusing on the cities of Barcelona and Rome, results show that there are energy savings between 14.46 and $25.02 \%$ in heating, and between 46.83 and $66.22 \%$ in cooling, whereas the total energy saving achieved savings between 42.66 and $58.16 \%$. On the other hand, Berlin, Bern and Vienna achieved energy savings between 7.03 and $12.85 \%$ in heating, and between 75.90 and $100 \%$ in cooling, whereas the total energy saving achieved savings between 14.49 and $26.42 \%$.

In all cases, the energy saving in cooling was greater than in heating. As for Barcelona and Rome, the reason could be that their climate is characterized by mild and high temperatures, and cooling consumption is greater. However, another reason could be that the temperature difference between static and adaptive setpoint temperatures was greater in cooling than in heating: In heating, the difference between the static setpoint temperature $\left(18^{\circ} \mathrm{C}\right)$ and the minimum adaptive $\left(17.1^{\circ} \mathrm{C}\right)$ was $0.9^{\circ} \mathrm{C}$, whereas in cooling, the difference between the static setpoint temperature $\left(27^{\circ} \mathrm{C}\right)$ and the maximum adaptive $\left(32.7^{\circ} \mathrm{C}\right)$ was $5.7^{\circ} \mathrm{C}$.

Table 5 analyzes the different energy savings obtained in heating and cooling by using the ACCIM. Columns Static-Adaptive Heating Consumption, Static-Adaptive Cooling Consumption, and Static-Adaptive Total Consumption are the result of the subtraction of the adaptive consumption from the static consumption in the modes of heating, cooling, and total, respectively. The column Cooling-Heating is the result of the subtraction of the heating saving from the cooling saving (i.e., the first and second columns previously mentioned), so positive values mean that the cooling saving predominates over the heating saving, and negative values mean the opposite. In the cities of Barcelona and Rome, the cooling energy saving was considerably higher than the heating energy saving, between 853.41 and $1267.98 \mathrm{kWh} /$ year. On the other hand, the energy saving in Berlin was greater in heating in all scenarios (varying between 67.49 and $448.51 \mathrm{kWh} /$ year), except in the RCP8.5 scenario, in which the cooling energy saving was greater by $22.74 \mathrm{kWh} /$ year. This tendency was similar in the cities of Bern and Vienna, in which the heating energy saving was greater in all scenarios (varying between 43.40 and $254.27 \mathrm{kWh} /$ year), except in RCP4.5 and RCP8.5 scenarios, in which the cooling energy saving was greater between 58.24 and $527.69 \mathrm{kWh} /$ year. In addition, the cooling saving in Vienna was slightly greater by $38.19 \mathrm{kWh} /$ year than the heating saving in the scenario A1B. 

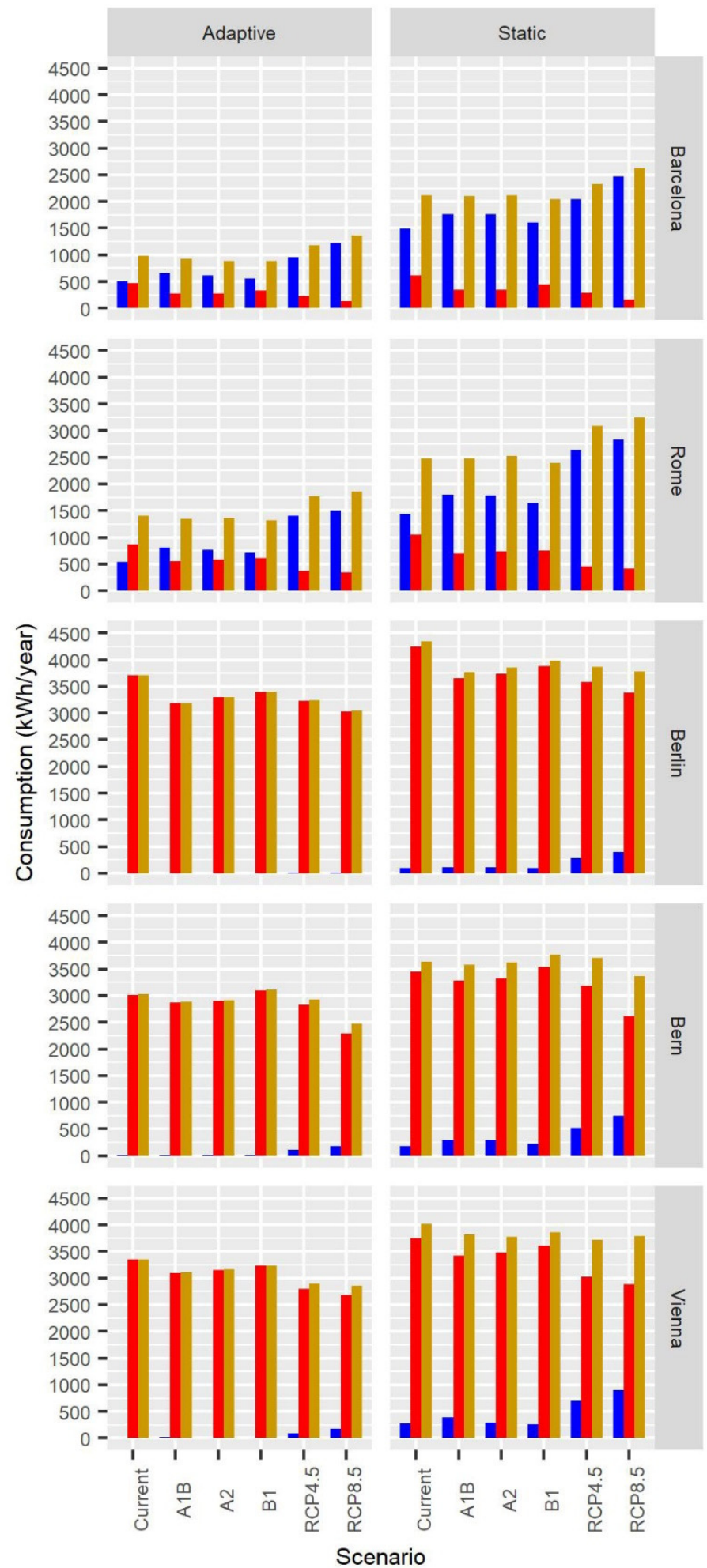
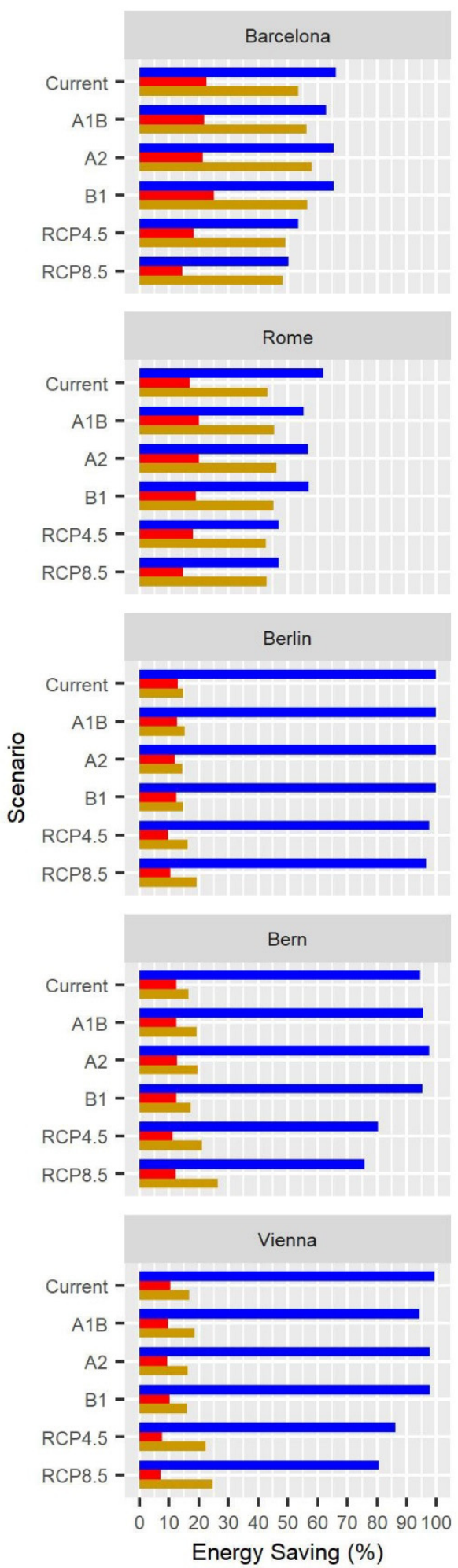

Energy Saving (\%)

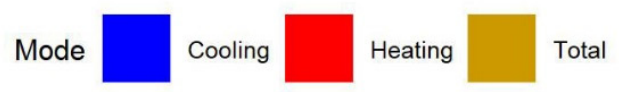

Figure 4. Energy consumption and energy savings provided by using the ACCIM. 
Table 5. Differences in the energy saving between heating and cooling.

\begin{tabular}{|c|c|c|c|c|c|}
\hline City & Scenario & $\begin{array}{c}\text { Static-Adaptive } \\
\text { Heating } \\
\text { Consumption } \\
\text { (kWh/year) }\end{array}$ & $\begin{array}{c}\text { Static-Adaptive } \\
\text { Cooling } \\
\text { Consumption } \\
\text { (kWh/year) }\end{array}$ & $\begin{array}{c}\text { Static-Adaptive } \\
\text { Total } \\
\text { Consumption } \\
\text { (kWh/year) }\end{array}$ & $\begin{array}{l}\text { Cooling-Heating } \\
\text { (kWh/year) }\end{array}$ \\
\hline \multirow{6}{*}{ Barcelona } & Current & 138.07 & 991.49 & 1129.56 & 853.41 \\
\hline & $\mathrm{A} 1 \mathrm{~B}$ & 75.01 & 1110.45 & 1185.46 & 1035.43 \\
\hline & $\mathrm{A} 2$ & 73.56 & 1153.86 & 1227.41 & 1080.30 \\
\hline & B1 & 111.47 & 1047.99 & 1159.46 & 936.52 \\
\hline & RCP4.5 & 52.07 & 1096.43 & 1148.50 & 1044.36 \\
\hline & RCP8.5 & 22.31 & 1238.54 & 1260.85 & 1216.23 \\
\hline \multirow{6}{*}{ Rome } & Current & 178.06 & 886.76 & 1064.81 & 708.70 \\
\hline & $\mathrm{A} 1 \mathrm{~B}$ & 137.65 & 993.85 & 1131.50 & 856.20 \\
\hline & A2 & 148.05 & 1017.08 & 1165.14 & 869.03 \\
\hline & $\mathrm{B} 1$ & 143.70 & 936.10 & 1079.80 & 792.40 \\
\hline & RCP4.5 & 81.37 & 1233.99 & 1315.36 & 1152.62 \\
\hline & RCP8.5 & 60.79 & 1328.77 & 1389.55 & 1267.98 \\
\hline \multirow{6}{*}{ Berlin } & Current & 546.57 & 98.05 & 644.62 & -448.51 \\
\hline & $\mathrm{A} 1 \mathrm{~B}$ & 466.91 & 109.49 & 576.39 & -357.42 \\
\hline & $\mathrm{A} 2$ & 447.62 & 110.40 & 558.02 & -337.22 \\
\hline & B1 & 487.56 & 104.61 & 592.17 & -382.95 \\
\hline & RCP4.5 & 347.55 & 280.05 & 627.60 & -67.50 \\
\hline & RCP8.5 & 353.03 & 375.77 & 728.80 & 22.74 \\
\hline \multirow{6}{*}{ Bern } & Current & 428.38 & 174.11 & 602.49 & -254.27 \\
\hline & $\mathrm{A} 1 \mathrm{~B}$ & 404.86 & 286.70 & 691.55 & -118.16 \\
\hline & A2 & 419.45 & 289.43 & 708.88 & -130.02 \\
\hline & B1 & 437.85 & 216.19 & 654.04 & -221.66 \\
\hline & RCP4.5 & 359.41 & 417.65 & 777.05 & 58.24 \\
\hline & RCP8.5 & 317.25 & 571.21 & 888.47 & 253.96 \\
\hline \multirow{6}{*}{ Vienna } & Current & 393.20 & 276.06 & 669.26 & -117.15 \\
\hline & $\mathrm{A} 1 \mathrm{~B}$ & 334.63 & 372.82 & 707.45 & 38.19 \\
\hline & A2 & 329.32 & 285.92 & 615.24 & -43.40 \\
\hline & B1 & 368.26 & 250.21 & 618.47 & -118.04 \\
\hline & RCP4.5 & 234.19 & 599.62 & 833.81 & 365.43 \\
\hline & RCP8.5 & 202.69 & 730.38 & 933.06 & 527.69 \\
\hline
\end{tabular}

\subsection{Variation of the Energy Consumption in Different Scenarios}

Figure 5 shows a considerable difference between the energy consumption in the SRES scenarios and the RCP scenarios: in the cities of Barcelona and Rome, energy consumption notably increased in the RCP scenarios, whereas in the cities of Berlin, Bern, and Vienna, it notably decreased.

Regarding the adaptive total energy consumption, in Barcelona and Rome there was a reduction in the SRES scenarios between 59.29 and 99.34 , and between 56.59 and $94.55 \mathrm{kWh} /$ year, respectively, whereas in the RCP scenarios, there was an increase between 198.94 and 376.09, and between 356.76 and $445.79 \mathrm{kWh} /$ year. In the cities of Berlin, Bern, and Vienna, this reduction in the energy consumption varied in the SRES scenarios between 311.98 and 513.89, between 114.15 and 136.67, and between 112.01 and $239.03 \mathrm{kWh} /$ year, respectively, whereas this reduction was generally greater in the RCP scenarios, varying between 467.12 and 657.78; 101.17 and 553.17; and 460.90 and $495.85 \mathrm{kWh} /$ year.

On the other hand, the static total energy consumption in the cities of Barcelona and Rome slightly increased and decreased in the SRES scenarios, whereas there were significant increases in the RCP scenarios, varying between 217.89 and 507.38, and between 607.30 and $770.54 \mathrm{kWh} /$ year. As for the cities of Berlin, Bern, and Vienna, such reduction in the energy consumption varied in the SRES scenarios between 364.43 and 582.12; 7.75 and 47.6; and 162.80 and $245.99 \mathrm{kWh} /$ year, whereas in the 
RCP scenarios the variation was between 484.14 and $573.60,-72.85$ (i.e., increasing consumption) and 267.19 , and 232.05 and $296.34 \mathrm{kWh} /$ year.

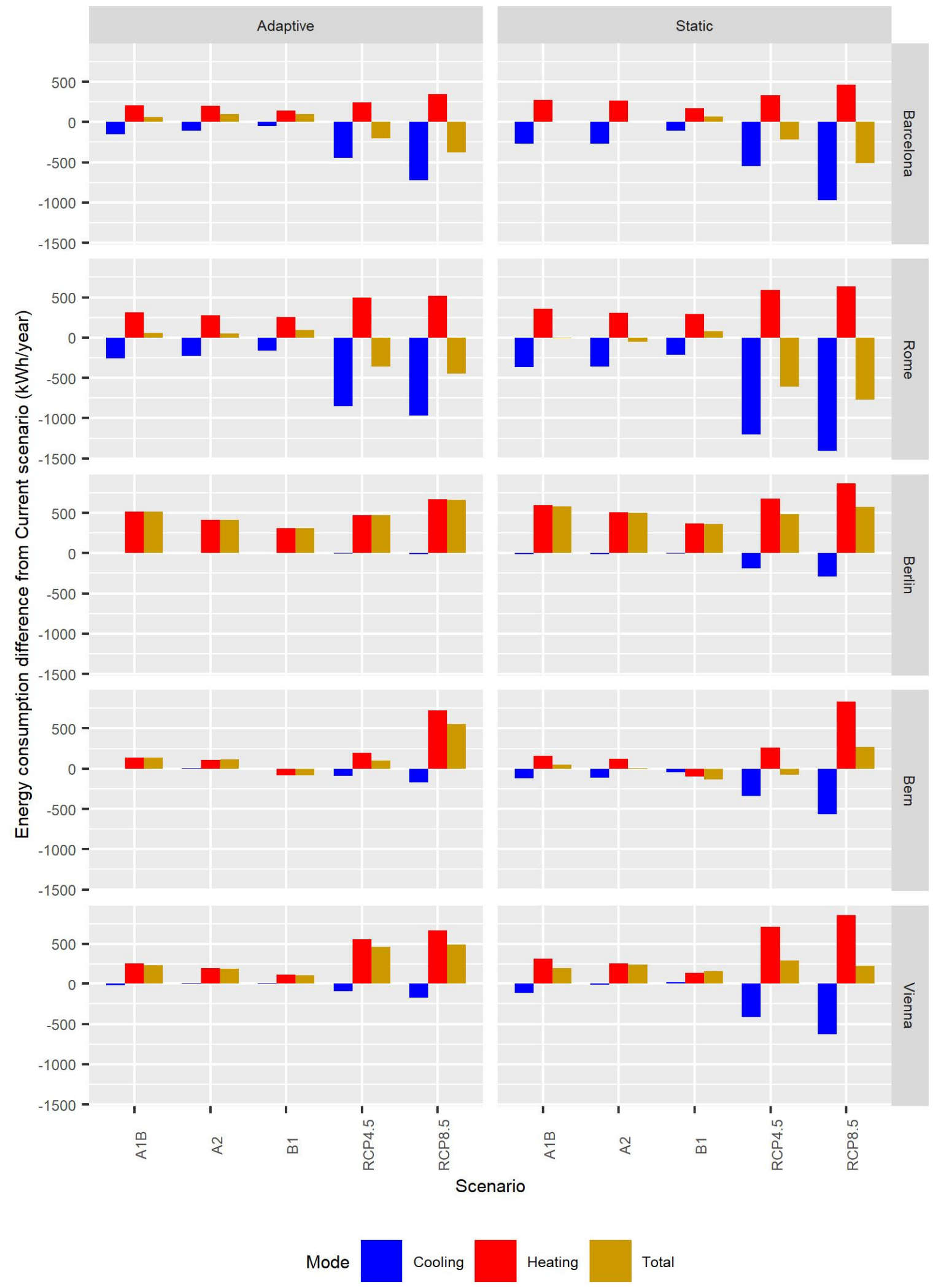

Figure 5. Energy consumption difference from current scenario, in which negative and positive values indicate increases and decreases, respectively. 
In B1 and RCP4.5 scenarios, the city of Bern did not have the same tendency of the cities of Berlin and Vienna as there were increases, instead of decreases, in the total consumption.

In addition, in Barcelona and Rome, the variation in heating prevailed over cooling in the SRES scenarios, whereas in the RCP scenarios the variation in cooling prevailed over heating. However, in Berlin, Bern, and Vienna, the variation in heating prevails both in the SRES scenarios and in the RCP scenarios.

\subsection{Thermal Comfort Levels}

This section analyses the thermal comfort levels for each scenario and in each location. The prototype is considered a single thermal zone, so operative temperature is constant in all rooms. Besides, it should be noted that Discomfortable Applicable Hot Hours and Discomfortable Applicable Cold Hours have been categorized as "comfortable" because in those situations occupants may adapt to the thermal environment if they are in a free-running building; for that reason the value of these two categories is always null. Table 6 depicts the most relevant information.

Table 6. Analysis of the number of applicable hours within the setpoints, outside applicability limits, and the total number of hours in which the operative temperature is within the setpoint temperatures.

\begin{tabular}{|c|c|c|c|c|c|c|c|}
\hline City & Scenario & $\begin{array}{c}\text { Comfortable } \\
\text { Hours }\end{array}$ & $\begin{array}{c}\text { Discomfortable } \\
\text { Applicable Hot } \\
\text { Hours }\end{array}$ & $\begin{array}{l}\text { Discomfortable } \\
\text { Applicable } \\
\text { Cold Hours }\end{array}$ & $\begin{array}{c}\text { Discomfortable } \\
\text { Non-Applicable } \\
\text { Hot Hours }\end{array}$ & $\begin{array}{l}\text { Discomfortable } \\
\text { Non-Applicable } \\
\text { Cold Hours }\end{array}$ & $\begin{array}{c}\text { Hours within } \\
\text { Setpoint } \\
\text { Temperatures }\end{array}$ \\
\hline \multirow{6}{*}{ Barcelona } & Current & 7655.75 & 0.00 & 0.00 & 48.00 & 1056.25 & 8746.00 \\
\hline & A1B & 7991.75 & 0.00 & 0.00 & 216.00 & 552.25 & 8746.75 \\
\hline & A2 & 8039.75 & 0.00 & 0.00 & 216.00 & 504.25 & 8746.00 \\
\hline & B1 & 7847.75 & 0.00 & 0.00 & 168.00 & 744.25 & 8747.75 \\
\hline & RCP4.5 & 7415.75 & 0.00 & 0.00 & 888.00 & 456.25 & 8749.50 \\
\hline & RCP8.5 & 7151.75 & 0.00 & 0.00 & 1272.00 & 336.25 & 8751.00 \\
\hline \multirow{6}{*}{ Rome } & Current & 7032.00 & 0.00 & 0.00 & 192.00 & 1536.00 & 8746.50 \\
\hline & A1B & 7367.75 & 0.00 & 0.00 & 288.00 & 1104.25 & 8745.00 \\
\hline & A2 & 7391.75 & 0.00 & 0.00 & 216.00 & 1152.25 & 8745.00 \\
\hline & B1 & 7271.75 & 0.00 & 0.00 & 168.00 & 1320.25 & 8746.00 \\
\hline & RCP4.5 & 6667.25 & 0.00 & 0.00 & 1276.50 & 816.25 & 8743.00 \\
\hline & RCP8.5 & 6743.75 & 0.00 & 0.00 & 1296.00 & 720.25 & 8729.75 \\
\hline \multirow{6}{*}{ Berlin } & Current & 4440.00 & 0.00 & 0.00 & 0.00 & 4320.00 & 8755.75 \\
\hline & A1B & 4776.00 & 0.00 & 0.00 & 0.00 & 3984.00 & 8754.75 \\
\hline & $\mathrm{A} 2$ & 4704.00 & 0.00 & 0.00 & 0.00 & 4056.00 & 8755.25 \\
\hline & B1 & 4584.00 & 0.00 & 0.00 & 0.00 & 4176.00 & 8757.00 \\
\hline & RCP4.5 & 4944.00 & 0.00 & 0.00 & 48.00 & 3768.00 & 8752.25 \\
\hline & RCP8.5 & 5256.00 & 0.00 & 0.00 & 0.00 & 3504.00 & 8754.00 \\
\hline \multirow{6}{*}{ Bern } & Current & 4632.00 & 0.00 & 0.00 & 0.00 & 4128.00 & 8758.00 \\
\hline & A1B & 4680.00 & 0.00 & 0.00 & 0.00 & 4080.00 & 8757.50 \\
\hline & $\mathrm{A} 2$ & 4656.00 & 0.00 & 0.00 & 0.00 & 4104.00 & 8757.25 \\
\hline & B1 & 4512.00 & 0.00 & 0.00 & 0.00 & 4248.00 & 8758.25 \\
\hline & RCP4.5 & 4920.00 & 0.00 & 0.00 & 48.00 & 3792.00 & 8754.00 \\
\hline & RCP8.5 & 5256.00 & 0.00 & 0.00 & 144.00 & 3360.00 & 8751.00 \\
\hline \multirow{6}{*}{ Vienna } & Current & 4872.00 & 0.00 & 0.00 & 0.00 & 3888.00 & 8756.00 \\
\hline & A1B & 4992.00 & 0.00 & 0.00 & 0.00 & 3768.00 & 8755.50 \\
\hline & $\mathrm{A} 2$ & 4944.00 & 0.00 & 0.00 & 0.00 & 3816.00 & 8755.00 \\
\hline & B1 & 4728.00 & 0.00 & 0.00 & 0.00 & 4032.00 & 8754.50 \\
\hline & RCP4.5 & 5400.00 & 0.00 & 0.00 & 120.00 & 3240.00 & 8752.25 \\
\hline & RCP8.5 & 5304.00 & 0.00 & 0.00 & 264.00 & 3192.00 & 8751.75 \\
\hline
\end{tabular}

In the cities of Barcelona and Rome, Comfortable Hours increased from the current scenario to the SRES scenarios, mainly because the decrease of Discomfortable Non-Applicable Cold Hours was greater than the increase of Discomfortable Non-Applicable Hot Hours, with the rise of temperature being 
the origin of both. However, this rise of temperature was greater in the RCP scenarios, thus leading to an increase of Discomfortable Non-Applicable Hot Hours, which were greater than the decrease of Discomfortable Non-Applicable Cold Hours, so the number of Comfortable Hours decreased. In the cities of Berlin, Bern, and Vienna, Comfortable Hours increased in all scenarios, except for the B1 in the cities of Bern and Vienna. On top of that, the number of Discomfortable Non-Applicable Hot Hours was 0 in the SRES scenarios, whereas in the RCP scenarios, the rise of temperature increased this number, although it continued to be lower than the decrease of Discomfortable Non-Applicable Cold Hours.

The rise of temperature consequently increased the running mean outdoor temperature. Figure 6 shows this increase in the $25 \%, 50 \%$, and $75 \%$ quartiles, represented by horizontal black lines in each chart. In the cities of Barcelona and Rome, the average of the RMOT in the SRES scenarios increased between 0.5 and $1.1{ }^{\circ} \mathrm{C}$, and between 0.2 and $0.6^{\circ} \mathrm{C}$, respectively, whereas in the RCP scenarios, the increase was between 1.9 and $2.9^{\circ} \mathrm{C}$, and between 2.6 and $3{ }^{\circ} \mathrm{C}$. In the cities of Berlin, Bern, and Vienna, the average of the RMOT increased between 0.7 and $1.1^{\circ} \mathrm{C} ; 0.1$ and $0.7^{\circ} \mathrm{C}$; and between 0.3 and $0.7^{\circ} \mathrm{C}$ in the SRES scenarios, whereas in the RCP scenarios, it was between 1.6 and $2.1^{\circ} \mathrm{C} ; 1.4$ and $2.7^{\circ} \mathrm{C}$; and 2.1 and $2.8^{\circ} \mathrm{C}$. This increase is also shown in Figures $7-11$, which include the cloud points corresponding to the operative temperature, the HST, and the CST in the static and adaptive model, as well as in the different scenarios and cities. As can be seen, all green points, which represent hours, were between the CST and the HST both in the adaptive and static model. As for the static model, there were two heating and cooling setpoint temperatures which corresponded to heating and cooling seasons. A heating and a cooling setpoint temperature corresponded to each hourly operative temperature. In such way, setpoint temperatures were horizontally extended, with operative temperatures so adjusted to the setpoint that they were almost hidden under each setpoint. There were also gaps in HST and CST as there were not any days with such temperature.

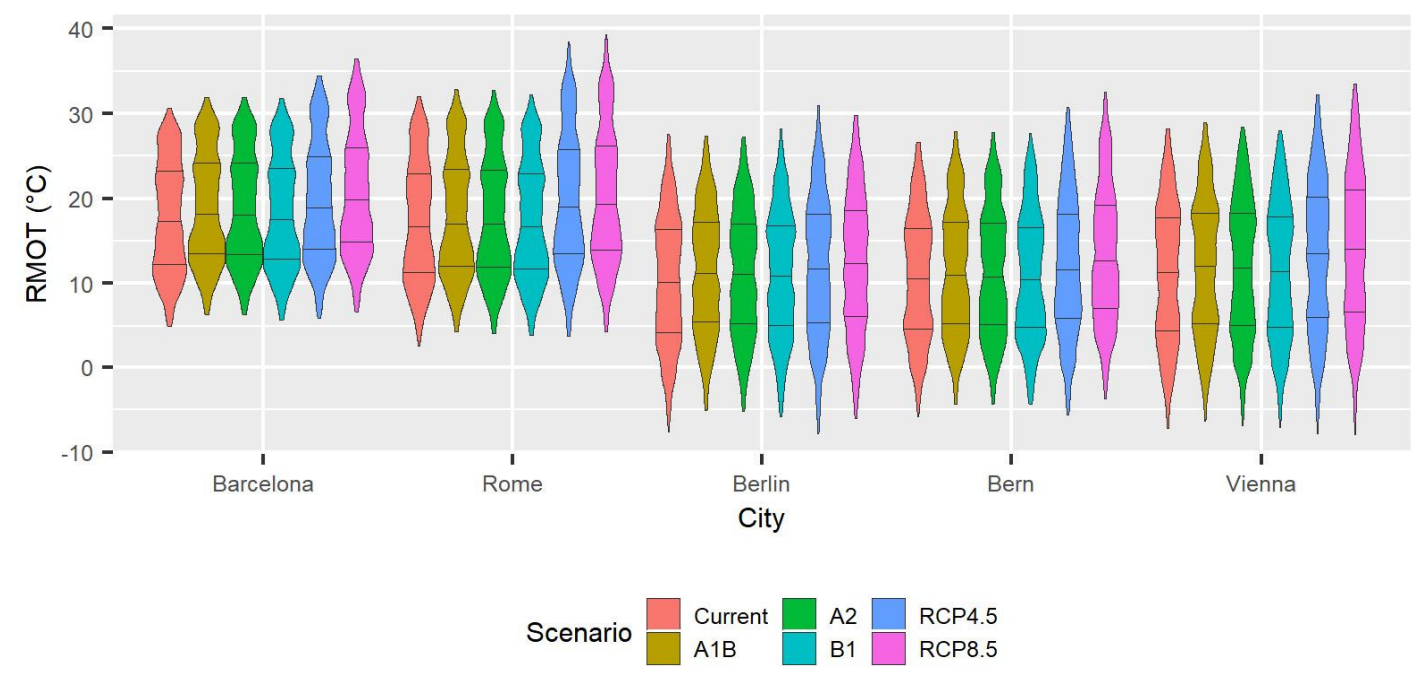

Figure 6. Violin plots of the RMOT in the different scenarios and cities. The horizontal lines in each violin plot refer to the $25 \%, 50 \%$ and $75 \%$ quartiles. 


\section{Barcelona}

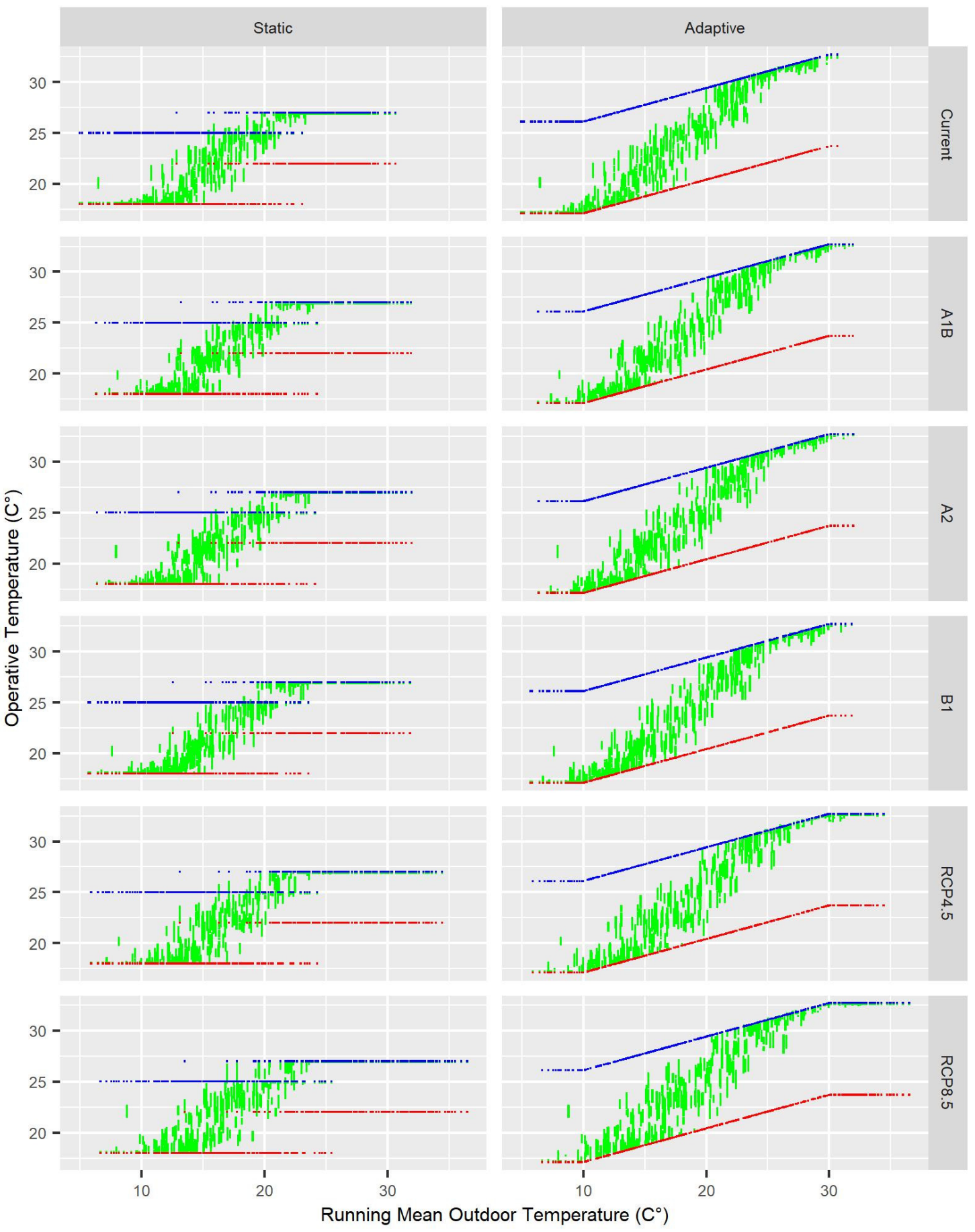

Temperature * Operative Temperature * CST . HST

Figure 7. Operative temperature in the city of Barcelona, based on comfort models and scenarios. 


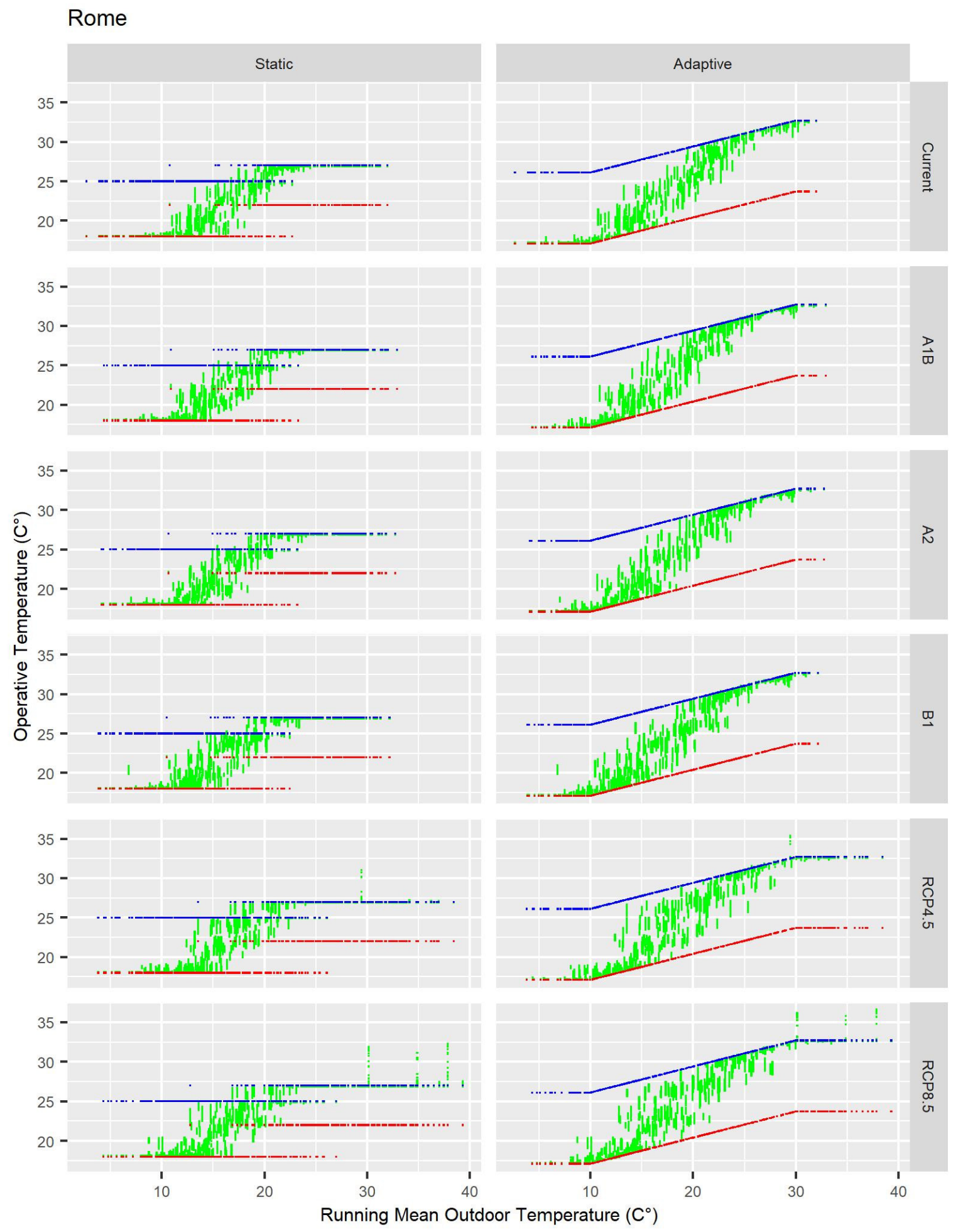

Temperature $\cdot$ Operative Temperature * CST $\cdot$ HST

Figure 8. Operative temperature in the city of Rome, based on comfort models and scenarios. 


\section{Berlin}
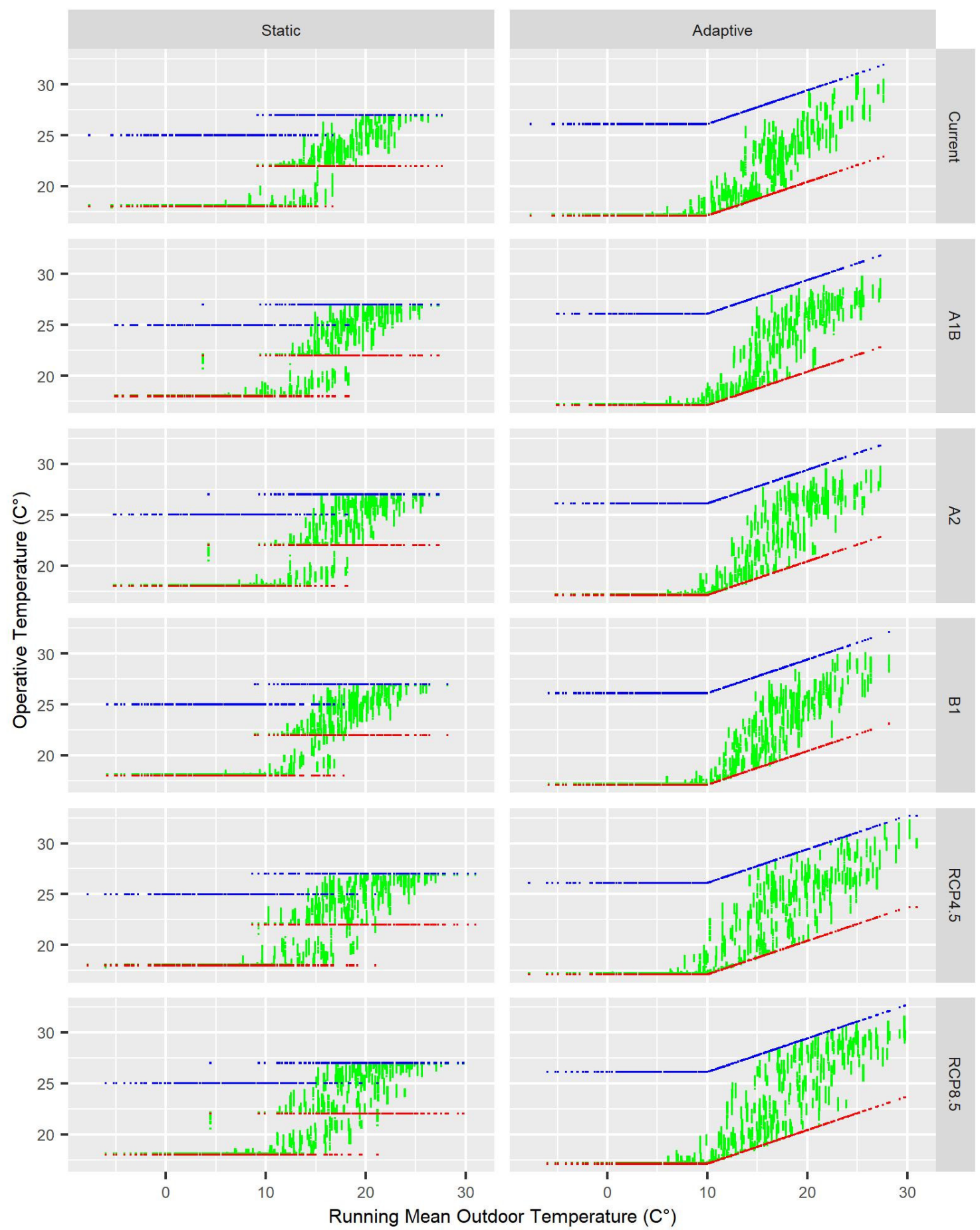

Temperature

Operative Temperature $\cdot$ CST $\cdot$ HST

Figure 9. Operative temperature in the city of Berlin, based on comfort models and scenarios. 


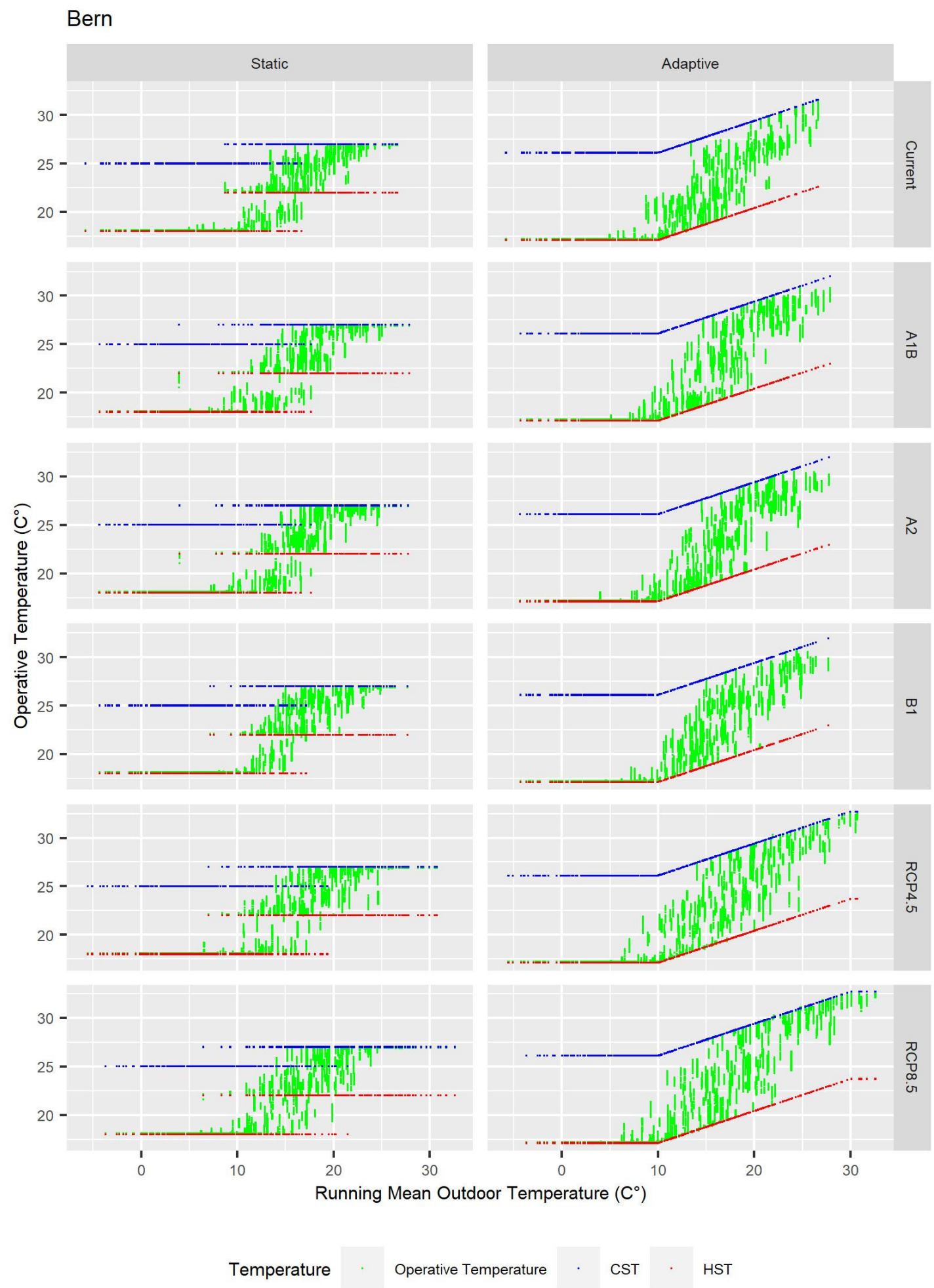

Figure 10. Operative temperature in the city of Bern, based on comfort models and scenarios. 


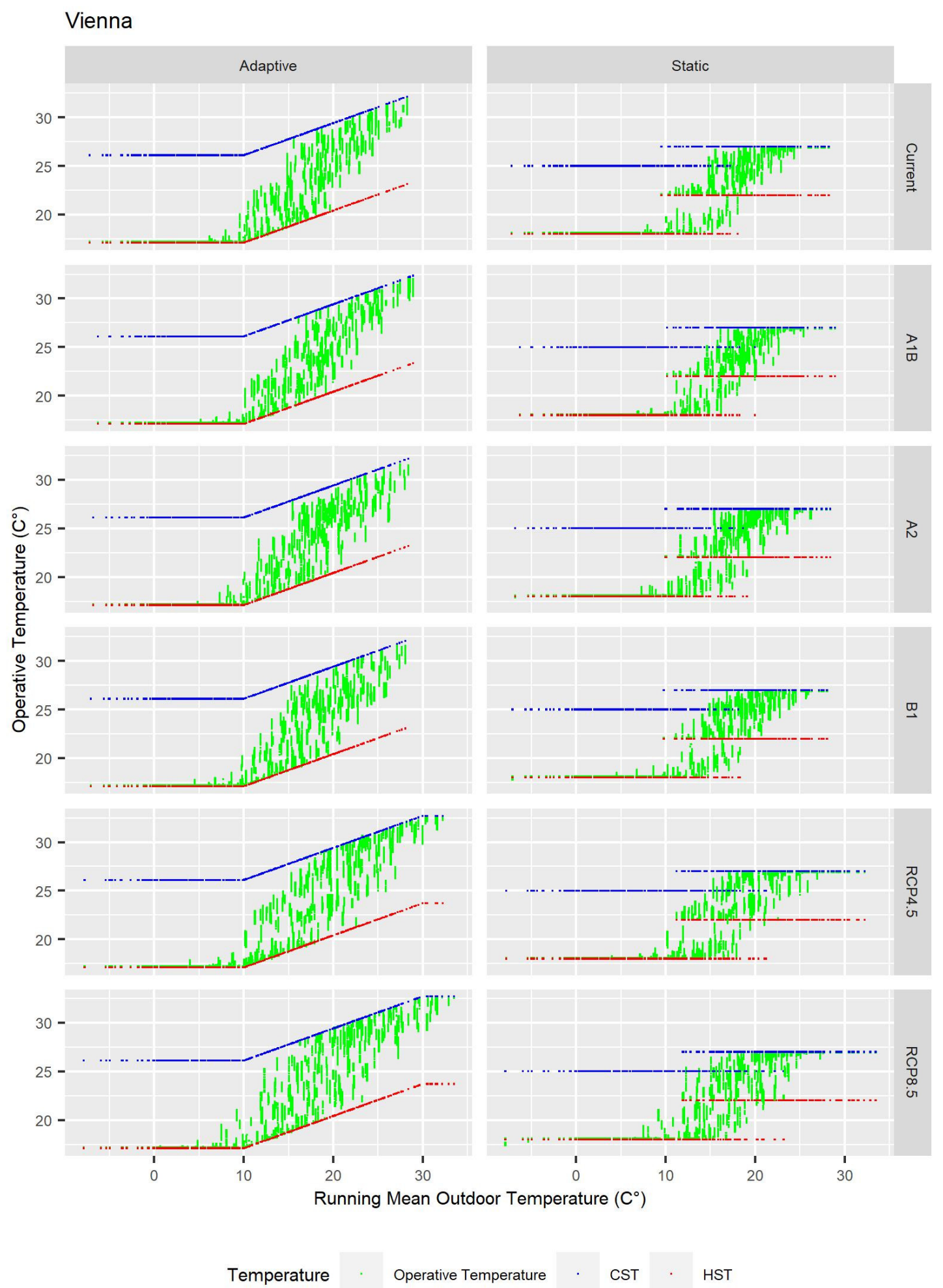

Figure 11. Operative temperature in the city of Vienna, based on comfort models and scenarios.

Columns Discomfortable Non-Applicable Hot Hours and Discomfortable Non-Applicable Cold Hours are the number of hours in which the adaptive model is not applicable, corresponding to the hours in which HST and CST are horizontally extended in the adaptive model (Figures 7-11). Nevertheless, it is important to stress that these data only affect the analysis of the applicability of the model, only leading to discomfort when the building does not have active systems. In this research, the active systems were in operation as they were needed during the non-applicable hours, obtaining 
in the worst case $99.65 \%$ of hours within the setpoint temperatures (in the RCP 8.5 scenario, in the city of Rome).

The current adaptive comfort model can assess adaptive thermal comfort levels in the current scenario. However, results regarding adaptive thermal comfort levels in future scenarios is limited as the adaptation to the increasing temperatures has not been considered, because the thermal acceptability and comfort thresholds of human beings might change as they adapt to increasing temperatures caused by climate change. Therefore, in the case that thermal adaptation was considered, energy saving potential might grow, as human beings would consider higher temperatures acceptable, so cooling adaptive setpoint temperatures could be higher than those actually calculated.

\section{Conclusions and Discussions}

This research aimed at clarifying the variation in the energy consumption of a prototype residential building located in five representative European cities. Heating and cooling consumption were analyzed under five different scenarios of climate change, also in relation with the applicability of the adaptive thermal comfort model through the ACCIM. The main conclusions of the study are as follows:

The ACCIM shows a great potential to reduce heating and cooling energy consumption, but some considerations should be made when implementing this model in different locations. Cities in the Mediterranean arch seem to benefit from significant reductions in the cooling consumption (around $50-60 \%$ ) in contrast with discrete savings for heating (around 20\%). On the other hand, the energy consumption for cooling in northern cities can be practically disregarded and savings for heating are very discrete (around 10\%). In general, future climate scenarios seem to have a slightly positive impact in northern Europeans cities and not exert a remarkable influence in the cities located in the Mediterranean basin.

According to this study, it can also be concluded that adaptive setpoint temperature should be adopted to contain the energy consumption in future climate scenarios; that seems to hold true for every considered location and scenario, but attention should be paid to the particularities of each city. Once more, with regard to the climate context, a distinction can be made between Mediterranean and northern cities. In the first group, savings for cooling are predominant and ACCIM will be able to contain, albeit to a moderate degree, the rise in energy consumption; that seems to be especially evident in the RCP scenarios. In contrast, northern European cities will greatly benefit from the shift from static to adaptive setpoints because it might allow in practice for a complete elimination of the cooling consumption, which seems to be particularly evident under RCP scenarios.

This study also concludes that, with regard to thermal comfort levels, conclusions are not crystal-clear, as two pressing questions might arise. First, for Mediterranean cities, even if adaptive models are considered, the number of hours in comfort will be reduced, especially because of the dramatic rise of the hours when temperatures exceed the limits of the model. In contrast, northern Europeans will benefit from milder temperatures and from a nearly non-existing discomfort associated to hot temperatures. Second, the question on how the adaptive model might be modified to adapt to these changing conditions remains unclear, although this study can provide some hints. No modification might be necessary regarding its lower limit, but higher limits should be put under serious consideration; this study suggest that occupants would accept operative temperatures over $30^{\circ} \mathrm{C}\left(30-32.5^{\circ} \mathrm{C}\right.$ for northern European cities and $30-35{ }^{\circ} \mathrm{C}$ for Mediterranean cities), but further research is deemed necessary to clarify this matter. Indeed, previous research also pointed out the scarcity of data over $30^{\circ} \mathrm{C}$, which makes it difficult to draw conclusions about thermal adaptability for hot temperatures [40]. This study also pointed out that cultural preferences and levels of expectation might play a relevant role in thermal adaptation; this claim has been supported by similar research, which concluded that the equations for the adaptive model should be modified for dry and humid hot climates [41]. On top of that, as previously mentioned, measurements for thermal comfort are subject to a certain degree of uncertainty [30] and that might be especially relevant under extreme temperatures. This calls for 
studies focusing especially on warm climates in order to clarify how adaptive comfort operates under hot conditions, for which data is relatively scarce.

In order to tackle this future research, it is also important to acknowledge the limitations of the present study. First, the present study has considered five cities that, despite being representative of the European context, might not grasp the entirety of the continent. In this respect, the authors have published a study focused on the applicability of the adaptive comfort model in a broader geographical context [16] and a similar study focusing in Europe alone would be desirable. Besides, building typologies, profiles of use and constructive features have been considered the same for all locations, although the five cities are located in very different contexts; on one hand, this was considered necessary to have a common framework for assessment, in line with similar studies [34,35], but, on the other hand, it is true that the conclusions of this study remain valid only under the assumption that building characteristics are the same for all locations. To overcome this limitation, future research should establish first a base-case scenario for each location, which is representative of each cultural, technological and geographical context. In this respect, techniques such as parametric design, which generates different prototypes by combining several parameters, have proven to be reliable approaches with insightful results in previous studies on tertiary buildings [42].

Second, conclusions from this study refer to year 2050; however, there is a degree of uncertainty in these predictive models and, on top of that, they cover a much broader range, until year 2300 [3]. Therefore, these conclusions should be understood as a stepping stones towards the prediction of future scenarios. In subsequent climate scenarios, this effect could become unfavorable, similarly to the RCP scenarios in the cities of Barcelona and Rome, a claim based on previous studies in a country with a great variety of climates such as Chile; for years 2020, 2050 and 2080, it could be argued that the effects of climate change on energy consumption patterns might greatly vary depending on the year considered [43].

In conclusion, despite its limitations, this study provides insightful knowledge about how the ACCIM might be of help when trying to cope with a changing climate in the year 2050. The beneficial effects on the energy consumption seem to be evident, but a deeper analysis is needed regarding the acceptability of occupants in hot conditions. This will allow for a new and flexible understanding of the interplay between buildings, occupants and climate in a context where environmental issues are pressing society to embrace a new frame of mind regarding its relationship with the surrounding environment.

Author Contributions: Conceptualization, methodology, investigation, writing-original draft preparation, writing-review and editing and visualization, D.S.-G., D.B.-H., J.A.P.-A. and C.R.-B. All authors have read and agreed to the published version of the manuscript.

Funding: This research received no external funding.

Conflicts of Interest: The authors declare no conflict of interest.

\section{Nomenclature}

$\begin{array}{ll}\text { ACCIM } & \text { Adaptive Comfort Control Implemented Model } \\ \text { AR4 } & \text { Fourth Assessment Report } \\ \text { AR5 } & \text { Fifth Assessment Report } \\ \text { CMIP5 } & \text { Coupled Model Intercomparison Project } \\ \text { COP } & \text { Coefficient of Performance } \\ \text { CST } & \text { Cooling setpoint temperatures } \\ \text { EER } & \text { Energy Efficiency Ratio } \\ \text { HST } & \text { Heating setpoint temperatures } \\ \text { HVAC } & \text { Heating, Ventilation and Air-Conditioning } \\ \text { PMV } & \text { Predicted Mean Vote Index } \\ \text { RCP } & \text { Representative Concentration Pathway } \\ \text { RF } & \text { radiative forcing } \\ \text { RMTOT } & \text { Running mean outdoor temperature } \\ \text { SRES } & \text { Special Report on Emissions Scenarios } \\ \text { VRF } & \text { Variable Refrigerant Flow }\end{array}$




\section{References}

1. Revd, M.H. Thermal comfort temperatures world-wide-The current position. Renew. Energy 1996, 8, 139-144. [CrossRef]

2. World Wildlife Fund. Living Planet Report 2014: Species and Spaces, People and Places; WWF International: Gland, Switzerland, 2014; Volume 1, ISBN 9780874216561.

3. Meinshausen, M.; Smith, S.J.; Calvin, K.; Daniel, J.S.; Kainuma, M.L.T.; Lamarque, J.; Matsumoto, K.; Montzka, S.A.; Raper, S.C.B.; Riahi, K.; et al. The RCP greenhouse gas concentrations and their extensions from 1765 to 2300. Clim. Chang. 2011, 109, 213-241. [CrossRef]

4. European Commission. A Roadmap for Moving to a Competitive Low Carbon Economy in 2050; European Commission: Brussels, Belgium, 2011; pp. 1-15.

5. Horne, R.; Hayles, C. Towards global benchmarking for sustainable homes: An international comparison of the energy performance of housing. J. Hous. Built Environ. 2008, 23, 119-130. [CrossRef]

6. Page, J.; Robinson, D.; Morel, N.; Scartezzini, J.L. A generalised stochastic model for the simulation of occupant presence. Energy Build. 2008, 40, 83-98. [CrossRef]

7. Pérez-Lombard, L.; Ortiz, J.; Pout, C. A review on buildings energy consumption information. Energy Build. 2008, 40, 394-398. [CrossRef]

8. European Commission Directive 2002/91/EC of the European Parliament and of the council of 16 December 2002 on the energy performance of buildings. Off. J. Eur. Union 2002, 65-71.

9. European Union. Directive 2010/31/EU of the European Parliament and of the Council of 19 May 2010 on the Energy Performance of Buildings; European Union: Brussels, Belgium, 2010; Volume 153, pp. 13-35.

10. Hoyt, T.; Arens, E.; Zhang, H. Extending air temperature setpoints: Simulated energy savings and design considerations for new and retrofit buildings. Build. Environ. 2014, 88, 89-96. [CrossRef]

11. Parry, M.L.; Canziani, O.F.; Palutikof, J.P.; van der Linden, P.J.; Hanson, C.E. Contribution of Working Group Ii to the Fourth Assessment Report of the Intergovernmental Panel on Climate Change; Cambridge University Press: Cambridge, UK, 2007.

12. Wan, K.K.W.; Li, D.H.W.; Lam, J.C. Assessment of climate change impact on building energy use and mitigation measures in subtropical climates. Energy 2011, 36, 1404-1414. [CrossRef]

13. Lakeridou, M.; Ucci, M.; Marmot, A.; Ridley, I. The potential of increasing cooling set-points in air-conditioned offices in the UK. Appl. Energy 2012, 94, 338-348. [CrossRef]

14. Spyropoulos, G.N.; Balaras, C.A. Energy consumption and the potential of energy savings in Hellenic office buildings used as bank branches-A case study. Energy Build. 2011, 43, 770-778. [CrossRef]

15. Fernandez, N.; Katipamula, S.; Wang, W.; Huang, Y.; Liu, G. Energy savings modelling of re-tuning energy conservation measures in large office buildings. J. Build. Perform. Simul. 2015, 8, 391-407. [CrossRef]

16. Bienvenido-Huertas, D.; Rubio-Bellido, C.; Pérez-Fargallo, A.; Pulido-Arcas, J.A. Energy saving potential in current and future world built environments based on the adaptive comfort approach. J. Clean. Prod. 2019, 119306. [CrossRef]

17. Sánchez-Guevara Sánchez, C.; Mavrogianni, A.; Neila González, F.J. On the minimal thermal habitability conditions in low income dwellings in Spain for a new definition of fuel poverty. Build. Environ. 2017, 114, 344-356. [CrossRef]

18. Schoen, L.J.; Alspach, P.F.; Arens, E.A.; Aynsley, R.M.; Bean, R.; Eddy, J.; Int-hout, D.; Khalil, E.E.; Simmonds, P.; Stoops, J.L.; et al. ANSI/ASHRAE 55:2013 Thermal Environmental Conditions for Human Occupancy. ASHRAE Stand. 2013, 2013.

19. Van Der Linden, A.C.; Boerstra, A.C.; Raue, A.K.; Kurvers, S.R.; De Dear, R.J. Adaptive temperature limits: A new guideline in the Netherlands: A new approach for the assessment of building performance with respect to thermal indoor climate. Energy Build. 2006, 38, 8-17. [CrossRef]

20. Boerstra, A.C.; van Hoof, J.; van Weele, A.M. A new hybrid thermal comfort guideline for the Netherlands: Background and development. Archit. Sci. Rev. 2015, 58, 24-34. [CrossRef]

21. Sánchez-García, D.; Bienvenido-Huertas, D.; Tristancho-Carvajal, M.; Rubio-Bellido, C. Adaptive Comfort Control Implemented Model (ACCIM) for Energy Consumption Predictions in Dwellings under Current and Future Climate Conditions: A Case Study Located in Spain. Energies 2019, 12, 1498. [CrossRef] 
22. Sánchez-García, D.; Rubio-Bellido, C.; del Río, J.J.M.; Pérez-Fargallo, A. Towards the quantification of energy demand and consumption through the adaptive comfort approach in mixed mode office buildings considering climate change. Energy Build. 2019, 187, 173-185. [CrossRef]

23. Sánchez-García, D.; Rubio-Bellido, C.; Tristancho, M.; Marrero, M. A comparative study on energy demand through the adaptive thermal comfort approach considering climate change in office buildings of Spain. Build. Simul. 2020, 13, 51-63. [CrossRef]

24. European Committee for Standardization. EN 15251: Indoor Environmental Input Parameters for Design and Assessment of Energy Performance of Buildings-Addressing Indoor Air Quality, Thermal Environment, Lighting and Acoustics; European Committee for Standardization: Brussels, Belgium, 2007; Volume 3, pp. 1-52.

25. Bienvenido-Huertas, D.; Sánchez-García, D.; Rubio-Bellido, C.; Oliveira, M.J. Influence of adaptive energy saving techniques on office buildings located in cities of the Iberian Peninsula. Sustain. Cities Soc. 2020, 53, 101944. [CrossRef]

26. Bienvenido-Huertas, D.; Sánchez-García, D.; Rubio-Bellido, C. Comparison of energy conservation measures considering adaptive thermal comfort and climate change in existing Mediterranean dwellings. Energy 2020, 190, 116448. [CrossRef]

27. Fanger, P.O. Thermal Comfort-Analysis and Applications in Environmental Engineering; Danish Technical Press: Copenhagen, Denmark, 1970.

28. Fanger, P.O. Calculation of thermal comfort: Introduction of a basic comfort equation. ASHRAE Trans. 1967, 73.

29. D'Ambrosio Alfano, F.R.; Olesen, B.W.; Palella, B.I.; Riccio, G. Thermal comfort: Design and assessment for energy saving. Energy Build. 2014, 81, 326-336. [CrossRef]

30. Wang, J.; Wang, Z.; de Dear, R.; Luo, M.; Ghahramani, A.; Lin, B. The uncertainty of subjective thermal comfort measurement. Energy Build. 2018, 181, 38-49. [CrossRef]

31. d'Ambrosio Alfano, F.R.; Olesen, B.W.; Palella, B.I.; Pepe, D.; Riccio, G. Fifty years of PMV model: Reliability, implementation and design of software for its calculation. Atmosphere 2020, 11, 49. [CrossRef]

32. Dear, R.J.; De, G.S. Brager Thermal comfort in naturally ventilated buildings: Revision to ASHRAE standards 55. J. Energy Build. 2002, 34, 549-561. [CrossRef]

33. European Committee for Standardization. EN 16798-1:2019. Energy Performance of Buildings-Ventilation for Buildings_Part 1: Indoor Environmental Input Parameters for Design and Assessment of Energy Performance of Buildings Addressing Indoor air Quality, Thermal Environment, Lighting and Acoustics-Module M1-6; European Committee for Standardization: Brussels, Belgium, 2019.

34. Rodrigues, E.; Fernandes, M.S.; Gaspar, A.R.; Gomes, Á.; Costa, J.J. Thermal transmittance effect on energy consumption of Mediterranean buildings with different thermal mass. Appl. Energy 2019, 252, 113437. [CrossRef]

35. Bienvenido-Huertas, D.; Quiñones, J.A.F.; Moyano, J.; Rodríguez-Jiménez, C.E. Patents Analysis of Thermal Bridges in Slab Fronts and Their Effect on Energy Demand. Energies 2018, 11, 2222. [CrossRef]

36. Randall, D.A.; Wood, R.A.; Bony, S.; Colman, R.; Fichefet, T.; Fyfe, J.; Kattsov, V.; Pitman, A.; Shukla, J.; Srinivasan, J.; et al. Climate Models and Their Evaluation; Cambridge University Press: Cambridge, UK; New York, NY, USA, 2007; Volume 323.

37. Taylor, K.E.; Stouffer, R.J.; Meehl, G.A. An overview of CMIP5 and the experiment design. Bull. Am. Meteorol. Soc. 2012, 93, 485-498. [CrossRef]

38. Taylor, K.E.; Stouffer, R.J.; Meehl, G.A. A Summary of the CMIP5 Experiment Design. World 2007, 4, 1-33.

39. Collins, M.; Knutti, R.; Arblaster, J.; Dufresne, J.L.; Fichefet, T.; Friedlingstein, P.; Gao, X.; Gutowski, W.J.; Johns, T.; Krinner, G.; et al. Long-Term Climate Change: Projections, Commitments and Irreversibility; Cambridge University Press: Cambridge, UK, 2013; Volume 9781107057.

40. Humphreys, M.A.; Rijal, H.B.; Nicol, J.F. Updating the adaptive relation between climate and comfort indoors; new insights and an extended database. Build. Environ. 2013, 63, 40-55. [CrossRef]

41. Toe, D.H.C.; Kubota, T. Development of an adaptive thermal comfort equation for naturally ventilated buildings in hot-humid climates using ASHRAE RP-884 database. Front. Archit. Res. 2013, 2, 278-291. [CrossRef] 
42. Rubio-Bellido, C.; Pérez-Fargallo, A.; Pulido-Arcas, J. Energy Optimization and Prediction in Office Buildings: A Case Study of Office Building Design in Chile; Springer: Berlin/Heidelberg, Germany, 2018; ISBN 9783319901466.

43. Rubio-Bellido, C.; Pérez-Fargallo, A.; Pulido-Arcas, J.A. Optimization of annual energy demand in office buildings under the influence of climate change in Chile. Energy 2016, 114, 569-585. [CrossRef]

(C) 2020 by the authors. Licensee MDPI, Basel, Switzerland. This article is an open access article distributed under the terms and conditions of the Creative Commons Attribution (CC BY) license (http://creativecommons.org/licenses/by/4.0/). 